\title{
Türkiye'de Geleneksel Mahalle Kimliğinin Sürdürülebilirliğinin Yarışma Projeleri Üzerinden İncelenmesi
}

\author{
Pınar TUĞCU ${ }^{1 *}$, Tülin Vural ARSLAN²
}

Öz

Hızlı kentleşme süreci ile birlikte değişen yaşam biçimleri Türkiye'de yerel kimlik özelliklerini yansıtan mahalle yapısının değişmesine neden olmaktadır. Kentlerde ortaya çıkan yeni mekânların birbirini tekrarlar nitelikte olması sahip oldukları kimlik özelliklerini ortadan kaldırarak tek tip mekânlar ortaya çıkartmaktadır. İnsan ölçeğinden uzaklaşan uygulamaların standartlaştırımış/basmakalıp yeni yaşam biçimleri sunması dünyada da yaygınlaşan yerelliğin ön plana alındığı çalışmaların gerekliliğini ortaya koymaktadır. Bu bağlamda Türkiye'de de dönüşüm geçirmekte olan kentlerde yapılan uygulamaların yerel kimliği vurgulayacak şekilde gerçekleştirilmesi hedeflenerek, toplumun belleğinde önemli bir yere sahip olan ancak unutulmaya yüz tutmuş mahalle geleneğinin canlandırılmasına yönelik çalışmalar başlatılmıştır. TOKI-Emlak Konut GYO A.Ş. tarafından düzenlenen "7 İklim 7 Bölge: Mahalle Ulusal Mimari ve Kentsel Tasarım Fikir Yarışması" ve İlbank tarafından düzenlenen "Mahalle Tasarımı Fikir Yarışması" ile günümüz ihtiyaçlarına cevap veren ve aynı zamanda geleneksel bağlama sahip mahalle tasarımı yapılması amaçlanmıştır. Bu çalışma ile öncelikle mahalle kavramı ve mahalleyi oluşturan kimlik unsurlarının ele alınması ve daha sonra "7 İklim 7 Bölge: Mahalle Ulusal Mimari ve Kentsel Tasarım Fikir Yarışması" ve "Mahalle Tasarımı Fikir Yarışması" sonucunda ödül alan projelerde "mahalle" olgusunu oluşturan bu unsurların ne ölçüde dikkate alındığının araştıııması amaçlanmaktadır. ${ }^{3}$

Anahtar kelimeler: Kent Kimliği, Mahalle, Kentsel Dönüşüm, Yarışma Projeleri.

\section{Examination of the Sustainability of Traditional Neighborhood Identity in Turkey Via Competition Projects}

\begin{abstract}
The changing lifestyles along with the rapid urbanization process are caused changes in the neighborhood structure which shows local identity characteristics in our country. The repetition of the new spaces emerged in cities eliminates the identity characterictics they have and creates standardized spaces. Presenting standardized new lifestyles of the practices that are moving away from human scale reveal the necessity of the studies on the prominence of locality that are becoming more prevalent in the world. In this context, it was aimed to implement the practices in a way to emphasize the local identity in cities undergoing transformation also in Turkey and studies have been initiated to revive the neighborhood tradition which has an important place in the memory of society but has been forgotten. With "7 Climate 7 Region: Neighborhood National Architectural Design Competition" organized by TOKI- EMLAK GYO A.Ş. and "Neighborhood Design Idea Competition" organized by İlbank, it was aimed to make the neighborhood design that answers today's needs and also has traditional context. The aim of this study is firstly to examine the concept of neighborhood and the identity elements of the neighborhood and then to search the extent to which of these elements constitute the concept of neighborhood in the award winning projects of "7 Climate 7 Region: Neighborhood National Architectural Design Competition" and "Neighborhood Design Idea Competition".
\end{abstract}

Keywords: Urban Identity, Neighborhood, Urban Regeneration, Competition Projects.

\footnotetext{
${ }^{1}$ Yüksek Lisans Öğrencisi, Bursa Uludağ Üniversitesi Mimarlık Fakültesi Mimarlık Bölümü, tugcu_pinar@hotmail.com

2 Prof., Dr., Bursa Uludağ Üniversitesi Mimarlık Fakültesi Mimarlık Bölümü, tvural@uludag.edu.tr

${ }^{3}$ Bu çalışma Marmara Belediyeler Birliği Şehir Politikaları 2018 Yılı Tez Desteği Programı tarafından desteklenen yüksek lisans tez çalışması kapsamında hazırlanmıştır.

*ilgili Yazar / Corresponding Author: tugcu_pinar@hotmail.com

Gönderim Tarihi: 13.03.2019

Kabul Tarihi: 29.06.2019
} 


\section{GíRiş}

Türkiye'de son dönemde kentsel yenileme yöntemi ile gerçekleştirilen kentsel dönüşüm uygulamaları mevcut yerleşim yerlerinin yıkılıp yeniden yapılması şeklinde uygulanmaktadır. Kentsel dönüşüm uygulamaları farklı ölçeklerde yapılabilmekte olup, kimi zaman büyük bir çöküntü alanının yenilenmesine yönelik, kimi zaman da fiziksel ömrü biten tekil bir yapının yerinde yenilenmesi gibi örnekler ile karşımıza çıkmaktadır. Ancak afet riski altındaki binaların yenilenmesi ya da çöküntü alanlarının ıslahı gibi problemlere çözüm getirilmesi hedeflenirken uygulamaların sonucunda; yoğunluk artışı, bütüncül planlamadan uzak parçacı çözümler, rant kaygısının oluşması, hak kaybı, sosyal dışlanma, soylulaştırma, gibi yeni problemler de meydana gelmektedir. Kimlik sorunu da yapılan dönüşüm projeleri sonucunda en fazla eleştiri alan konulardan biridir. Hızlı ve ekonomik çözümler yerel kimlik özelliklerini bir kenara bırakarak beraberinde standartlaşmayı getirmektedir. Yapılan dönüşüm uygulamalarında ortaya çıkan ürünlerin birbirine benzer olması kentler arasındaki kimlik farklılıklarını da ortadan kaldırmaktadır. Mahalle dokusu yerine kapalı konut sitelerinin getirilmesi ile yaşanan mekânsal dönüşümler bir yandan mekânsal ayrışmayı getirirken diğer yandan kimlik özelliklerine sahip değerlerin kaybolmasına neden olmaktadır. Söz konusu dönüşüm sadece fiziksel çevre özellikleri olarak değil fiziksel çevre ile etkileşimde olan toplumsal ortak değerlerin de kaybolması şeklinde gerçekleşmektedir. Bu durumun sonuçları yerel kimlik özelliklerinin sürdürülmesinin önemi konusunda farkındalık yaratmış ve kentsel dönüşüm uygulamalarında kimlik arayışı ihtiyacı ortaya çıkmıştır.

$\mathrm{Bu}$ bağlamda Türkiye'de konut üretimi ve konut üretimine finansman sağlama konularında görev alan kurumlardan TOKI (Toplu Konut İdaresi Başkanlığı) ve Emlak GYO A.Ş. tarafından düzenlenen "7 İklim 7 Bölge: Mahalle Ulusal Mimari ve Kentsel Tasarım Fikir Yarışması" ile "Şehir 2023" çalışmaları kapsamında İller Bankası A.Ş. tarafından düzenlenen "Mahalle Tasarımı Fikir Yarışması" örnekleri ileride mahalle ölçeğinde yapılacak olan yeni uygulamalar için yerel kimlik unsurlarının sürdürülmesine yönelik farklı fikirlerin geliştirilmesine imkân veren bir platform sağlamıştır.

Geleneksel mahalle anlayışının günümüz ihtiyaçları doğrultusunda kurgulanması ve bu doğrultuda mahalle dokusu, mahalle kültürü, sosyal yaşam, sosyal bütünleşme, dayanışma, paylaşma, insan ölçeği, peyzaj, siluet, sokak, meydan gibi önemli kavramların ele alınmasının beklenildiği iki yarışma Türkiye'nin farklı iklim koşullarına ve kültürel değerlere sahip yedi bölgesindeki iller için çalışma imkânı sunarak mahalle kimliğinin oluşturulması ve sürdürülmesinde göz önüne alınacak tasarım kodlarının belirlenmesine katkı sağlamaktadır. Bu çalışma ile mahalle kavramı ve onu oluşturan kimlik kavramlarının literatür analizi yapılarak anlaşılması ve daha sonra düzenlenen iki yarışmada söz konusu kavramların hem mekânsal hem sosyal kurguda ne şekilde ele alındığının incelenmesini amaçlamaktadır.

\section{TÜRKIYE'DE KONUT ÜRETIMINDE GÖREV ALAN KAMU KURUMLARI: TOKI VE İLBANK}

Türkiye'de yürütülen konut politikası uygulamaları 1999 Marmara ve 2011 Van depremleri sonrasında kentsel dönüşüm kavramının yasalarda yer almasıyla birlikte hız kazanmıştır. Ekonomik ömrünü tamamlayan yapı stoku, afet riskli bulunan yerleşim alanları, gecekondu alanları, kent merkezlerinde çöküntü alanlarının oluşması ve son dönemde doğu illerinde yaşanan terör olaylarının getirdiği yıkımlar gibi süreçler kentlerdeki konut politikalarının şekillenmesinde etkili olmaktadır. Bu kapsamda Çevre 
ve Şehircilik Bakanlığı'nın ilgili iki kuruluşu olan TOKİ ve İller Bankası konut üretimi ve konut üretimine finans sağlanması konularında faaliyetler yürütmektedir.

Türkiye'de artan konut intiyacının planlı bir şekilde karşılanması amacıyla 1984 yılında yürürlüğe giren 2985 sayılı Toplu Konut Kanunu ile Toplu Konut ve Kamu Ortaklığı İdaresi Başkanlığı kurulmuş ve 1990 yılında bu kurum Toplu Konut İdaresi Başkanlığı ve Kamu Ortaklığı Başkanlığı şeklinde iki ayrı idare şeklinde örgütlenmiştir. TOKi özetle; doğrudan ya da iştirakçileri aracılığıyla konut, altyapı ve sosyal donatı projelerinin geliştirilmesi ve uygulanması, bakanlıklar ve diğer kamu kuruluşları ile yapılan protokoller kapsamında kamuya yönelik sosyal amaçı tesislerin yapılması, tescilli taşınmaz kültür varlıklarının bakımı, onarımı ve restorasyonu için kredi kullandırılması, arsa üretimi, AR-GE çalışmaları faaliyetlerini yürütmektedir. Konut politikaları kapsamında kentsel yenileme uygulamaları ile gecekondu, kaçak yapı alanları ve afet riskli bulunan alanların dönüştürülmesini sağlarken, yeni gecekondu alanlarının oluşumunun engellenmesi amacıyla alt gelir gruplarına yönelik konut üretimini gerçekleştirmektedir. Bugün TOKI'nin konut programında; sosyal konutlar, afet konutları, kentsel dönüşüm ve gelişim projeleri, idare konut uygulamaları, alt gelir grubu, tarımköy gibi uygulamalar yer almakta olup 81 ilde faaliyetlere devam edilmektedir (URL 1).

1933 yılında belediyelerin imar faaliyetlerinin finans edilmesi amacıyla "Belediyeler Bankası" adıyla kurulan İlbank, 2011 yılında 6107 sayılı Kanunla birlikte "iller Bankası A.Ş." adını almıştır. İller Bankası A.Ş. özel hukuk hükümlerine tabi, tüzel kişiliğe sahip, özel bütçeli anonim şirket statüsünde bir kalkınma ve yatıım bankasıdır (İller Bankası A.Ş., t.y.). Yerel yönetimlere kentsel intiyaçlarının karşılanması amacıyla proje üretmek ve geliştirmek, kredi sağlamak, danışmanlık yapmak ve teknik destek vermek yoluyla sürdürülebilir şehirleşmeye katkıda bulunmayı amaçlayan İlbank, 6306 sayılı Afet Riski Altındaki Alanların Dönüştürülmesi Hakkında Kanun kapsamında ilan edilen uygulama alanlarında ya da 5393 sayılı Belediye Kanunu'nun 73. Maddesi kapsamında ilan edilen kentsel dönüşüm ve gelişim alanlarında, T.C. Çevre ve Şehircilik Bakanlığı ve/veya Belediyeler ve/veya yetkili kurum/kuruluşlarla yapılan protokoller ile kentsel dönüşüm uygulamaları gerçekleştirmektedir. Çevre ve Şehircilik Bakanlığı ile imzalanan protokol çerçevesinde Silopi (Şırnak) Karşıyaka Mahallesi Rezerv Yapı Alanı'nda uygulanacak olan kentsel dönüşüm projesinin hazırlanması işi ve Karabağlar'da (İzmir) ilan edilen riskli alan uygulamaları bu kapsamda yürütülmektedir (iller Bankası A.Ş.,2017a).

Türkiye'de konut intiyacının önemli bir kısmını karşılayan TOKİ, gecekondu alanları ve afet riski taşıyan bölgelerde kentsel dönüşüm uygulamaları ile Türkiye genelinde faaliyetlerine devam etmektedir. Ancak kentsel dönüşüm ve gelişim amacıyla Türkiye'nin farklı bölgelerinde gerçekleştirilen ve hem görsel hem de fonksiyon olarak birbirine benzeyen TOKİ uygulamaları, uygulama alanının çevresiyle ve sosyal boyutla bütüncül bir şekilde ele alınmamaları ve katılım eksikliği gibi nedenlerle yerel kimlik ve kullanıcı memnuniyeti konularında eleştiri almaktadır (Gür ve Dostoğlu, 2016, s.104; Özbek Eren, 2014, s.20). Farklı illerde yürütülen TOKi konut uygulamaları standart özelliklere sahip olup bulundukları yere özgü bir kimlik özelliği göstermemektedir (Fot.1, 2, 3 ve 4). Hemen her ilde karşılaşılan yüksek katlı tip projeleri nedeniyle eleştirilen TOKİ son dönemde "yatay mimari" ve "mahalle konsepti" söylemleriyle uygulamalarına yeni bir yaklaşım getirileceği konusuna dikkat çekmektedir (URL 2). 


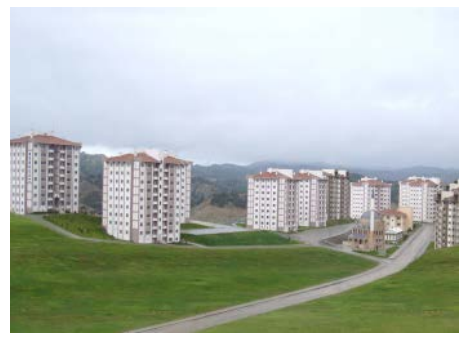

Fot. 1: Denizli (URL 1)

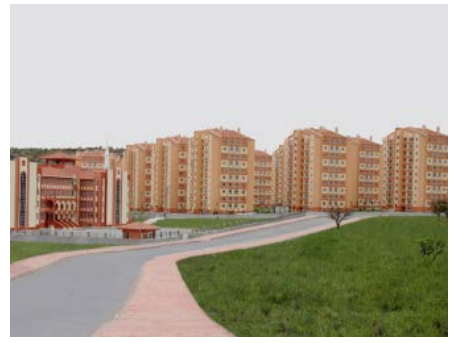

Fot. 3: Nevşehir (URL 1)

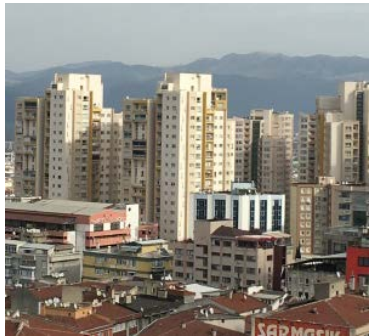

Fot. 2: Bursa (Pınar Tuğcu, 19.11.2018)

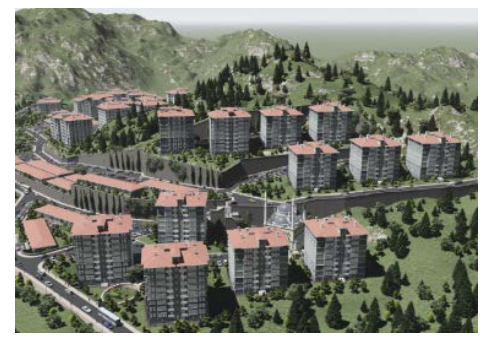

Fot. 4: Muş (URL 1)

\section{MAHALLE KAVRAMI VE MAHALLEYI OLUŞTURAN KIMLIK BILEŞENLERI \\ 3.1. Mahalle kavramı}

Toplumun belleğinde önemli bir yere sahip olan "mahalle" kavramı, büyük ve hızlı gelişen kentlerde değişime uğrayarak geleneksel bağlamından uzaklaşmaktadır. Geleneksel anlamda dayanışmanın, yardımlaşmanın, birlik olmanın, paylaşmanın ve komşuluğun oluşmasına ortam sağlayan ve aynı zamanda bir toplumun kültürel özelliklerini gösteren en küçük birim olan mahalle; fiziksel, sosyal, kültürel ve ekonomik boyutlarıyla bir bütün olarak kent kimliğinde önemli bir yere sahiptir.

Cumhuriyetin ilk yıllarından 1950'li yıllara kadar kent kurgusu içerisinde mahalle yapısında önemli değişimler görülmezken, 1950'lerde sanayileşmenin getirdiği kentleşme ile kent kurgusunda "apartmanlaşma", "gecekondulaşma" ve "toplu konut" oluşumları ortaya çıkmıştır. Bu dönemde mahallenin içyapısında büyük değişiklik olmasa da hızı kentleşmenin sonuçları olarak gelişi güzel kentleşme, sağlıksız konut, ulaşım ve altyapı, yüksek yoğunluk, güneşsiz ve yeşilsiz kentsel çevreler gibi sorunlar meydana gelerek bugünkü kent problemlerinin temeli atılmıştır. 1980'lerden sonra ise küreselleşmenin etkileri kendini göstermeye başlamıştır. Bu dönemde toplu konut fonunun yürürlüğe girmesi ile toplu konut alanlarında artış olmuştur. Yapılan imar planları ile geleneksel doku kaybolmuş, mahalle kurgusunda önemli bir yere sahip olan sokak geleneksel işlevini kaybederek ulaşım için kullanılmaya başlamıştır. Bu süreçte gecekondu alanlarının apartmanlaştıııması da mahalle kavramının sahip olduğu bazı değerlerin kaybolmasına neden olmuştur (Özbek Eren, 2012, s.1553; Şan 1999, s.3538).

Ekonominin dışa açıldığı 1980 sonrası dönemden 2000'li yıllara kadar kentteki gecekonduların çok katlı yapılara dönüşerek apartmanlaştığı görülmektedir. Bu dönemde kooperatif örgütlenmeleri, TOKI, özel girişimciler, Türkiye Emlak Bankası gibi örgütlenmelerin gerçekleştirdiği farklı toplu konut uygulamaları yaygınlaşmıştır. Konut, gecekondu, kültürel, tarihi, doğal çevre gibi özel alanları kapsayan yasal düzenlemeler getirilmiş ve kentsel dönüşüm uygulamaları yapılmaya başlanmıştır. 2000'li yıllarda ise 
kentsel dönüşümün yasalarda yer alması ile birlikte kentlerde 'dönüşüm' bir strateji olarak ele alınmaya başlanmıştır ve özel sektörle iş birliği bu dönemde hız kazanmıştır (Ataöv ve Osmay, 2007, s.52-65).

Son dönemde sadece kentlerdeki fiziksel dönüşümün değil yaşam biçimlerinin de hızla değişiyor olması geleneksel yaşam biçimini yansıtan mahallenin belleklerde kalarak sadece fiziksel bir sınır olarak tanımlanmasına neden olmaktadır. Bu nedenle yerelliğin ön plana alındığı çalışmalar ile belleklerde yerini koruyan mahalle ruhunun canlandırılması gündeme gelmiştir.

\subsection{Mahalle kurgusunun bileşenleri}

Kentin yapı taşı diyebileceğimiz mahalle birimi kent kimliği bileşenlerinin daha küçük ölçekte bir araya gelmesinden oluşmaktadır. Mahalle kurgusunu anlayabilmek için öncelikle mahalleyi oluşturan kimlik bileşenlerinin analiz edilmesi gerekmektedir.

Alver (2010, s.117) "mekân" ve "insan"ın mahallenin iki temel kurucu unsuru olduğunu söyleyerek, mahallenin bir metafor olarak dayanışma, yardımlaşma, komşuluk, denetim, kontrol, güvenlik, ortaklık, benzerlik, yakınlık, aidiyet gibi kavramları hatırlattığını belirtmektedir. Mekân ve insan, mahalle ve mahalleli karşılıklı etkileşim halinde olup birbirlerinin kimliğini şekillendirmektedir. Bu iki unsurun sahip olduğu alt bileşenler bir bütün oluşturarak yer kimliğini meydana getirmektedir.

Relph (1976, s:47) yer kimliği bileşenlerini fiziksel çevre, aktiviteler ve anlam olarak sıralamaktadır. Bir yeri anlatırken fiziksel ortam ve aktiviteler gözlemlenerek aktarılabilir ancak "anlam" kişinin o yer hakkındaki deneyimleriyle ilgili olarak hissettikleridir. Bu üç bileşen birbirinin yerine indirgenemeyeceği gibi yer deneyimlerimizde ayrılmaz bir biçimde iç içe geçmiş durumdadır.

Galster (2001, s.2112) de mahalleyi oluşturan mekânsal özellikleri konut ve konut dışı binaların yapısal özellikleri, altyapı özellikleri, yerleşik nüfusun demografik özellikleri, yerleşik nüfusun sınıf durumu özellikleri, vergi/kamu hizmeti özellikleri, çevre özellikleri, yakınlık özellikleri, siyasi özellikler, sosyal etkileşim ve duyusal özellikler olarak gruplandırmaktadır.

\subsubsection{Fiziksel kodlar}

Fiziksel kodlar, doğal ve yapılı çevre öğelerinin birleşiminden oluşmaktadır. Topografya, coğrafi özellikler, iklim, bitki örtüsü, hâkim rüzgâr yönü gibi bileşenler kimliğin belirlenmesinde doğal bileşenleri oluştururken, doğal çevre üzerine sonradan inşa edilen yapılar fiziksel kimliğin diğer boyutunu meydana getirir. Sokak/meydan birlikteliğinin oluşturduğu mekânlar, malzeme-renk-doku birleşimi, sınırlayıcılar ve yeşille olan ilişkiler bütünü yapılı çevreyi oluşturmaktadır (Demirseren Çöl, 1998, s.1516).

Fiziki bir birim olarak ele alındığında; sokaklar, caddeler, binalar, dükkânlar, evler, yollar mahallenin yerini belirginleştiren aynı zamanda sınırlarını da çizen unsurlardır (Alver, 2010, s.119).

Özbek Eren (2017, s.117) geleneksel mahalleyi temsil eden fiziksel/mekânsal kodları; morfolojik yapı/ ada-parsel-sokak, ölçek/insan-sokak-bina, tipoloji/bina-sokak tipleri, 
sınırlar/büyüklük, nirengi noktaları, odak/kamusal merkez, yerel yönetim temsil mekânı olarak sıralamaktadır.

Biçim, strüktür, oran-orantı, doku, malzeme, konum ve simgesel özellikler gibi faktörler de kullanıcı gereksinmelerinden doğan eylem alanları ve kullanıcılar tarafından tasarlanmış öğelerden oluşan yapay çevre elemanlarının kent ölçeğinde kimlik oluşumu bağlamında değerlendirilmesini sağlamaktadır (Kutlu, Manav ve Ertürk, 2011, s.7).

\subsubsection{Sosyal kodlar}

Sosyal kodlar, mahalle sakinleri ve onların yaşam biçimleri ile ilgilenmektedir. İnsanın hayatını sürdürme esasları ve bu esasların biçimleri mahalle kültürünü oluşturur. Orada nasıl yaşandığı, yaşantının hangi değerler, kaideler, inançlar, adetler, ritüeller, gelenek ve görenekler, töreler etrafında biçimlendiği sahip olduğu kültürün bir parçasıdır ve mahallenin kendi özgünlüğünü, farklılığını belirlemektedir. Mahalle hayatında kültür ve yaşam tarzlarının sergilendiği gündelik hayatta; sosyalleşme, komşuluk, dayanışma ve yardımlaşma, mahalle etkinlikleri, mahalle baskısı, dedikodu ve muhabbet, farklılıklar, ayrılıklar, çatışmalar gibi aktiviteler yer almaktadır (Alver, 2013, s.144).

Mahallede sürdürülen sosyal yaşantı aile içinden sonra komşuluk çevresinde geçmektedir. Aralarında kan bağı veya hemşerilik olsun ya da olmasın ortak mekânları paylaşıyor olmak günlük aktiviteler içinde dayanışma ve sosyalleşmenin gerçekleştirildiği yüz yüze ilişkileri içeren komşuluk birimi olan mahalle hayatının en önemli sosyal bileşenlerinden birini oluşturmaktadır.

Özbek Eren (2017, s.117) geleneksel mahalleyi temsil eden sosyal-zihinsel kodları; değerler sistemi, toplumsal hukuk, kültürel yapı, ideoloji-teknoloji, sosyal yapı ve kurumlar, demografik özellikler, politika-ekonomi-üretim olarak sıralamaktadır.

\subsubsection{Anlam}

Yer, anlam yüklenen mekâna işaret etmektedir. Kültür de insanların davranış ve değerlerini güçlü bir şekilde etkileyerek mekâna anlam katmalarında ve biçimlendirmelerinde etkili bir rol oynamaktadır (Altman ve Low, 1992, s.5; Tuan, 1997, s.5). Mahalleye anlam yükleyen mahalleli ve mahallelinin sosyo-kültürel özellikleridir. Bu nedenle bir yerin yerelliğinin sürdürülmesi için oraya anlam yükleyen kullanıcılarının sürece dâhil olmaları gerekmektedir.

Deneyimler, algı ve bellek yoluyla mekân üzerinde bir yer izlenimi yaratılır ve mahalle yaşamı esasında insan deneyimi, aidiyet, bellek, değerler etrafında örüntülenen mekân ile bütünselliğe dayanmaktadır (Özbek Eren, 2017, s.74).

Tanıdık bir yerle kurulan güçlü bağ aidiyet duygusunun gelişmesine katkıda bulunur. Etkileşim ve alışveriş kullanıcılar arasında aşinalık sağlar ve sokaklarla olan etkileşimi de teşvik eder. Bir yeri kullanıcılar için tanıdık ve anlamlı hale getiren yer duygusunun inşasında "zaman" önemli bir faktördür (Ujang, 2008, s.7). Lynch (1984, s.132) de yoğun aşinalığın yer duygusunu ortaya çıkaracağını söylemektedir.

Yere bağlıık, insanın mekânla etkileşiminde paylaştığı bir eğilimi ve mekâna yönelik yaşadığı duygusal bağı ifade etmektedir. Bir yerde yaşama süresi, güvenlik hissi, sosyal bağlar ise insanların yere bağılıklarını etkileyen en önemli bileşenlerdir. Söz konusu bağlılık tek taraflı bir oluşum olmayıp kişiler, kimlik ve mekânlar arasındaki 
karşılıklı etkileşimin sonucudur (Göregenli, Karakuş, Kösten ve Umuroğlu, 2014, s.7576).

Anlam, bireylerin yer ile kurmuş oldukları duyusal özellikleri ifade ettiğinden aidiyet, algı, aşinalık, ortaklık, yer duygusu, yere bağlılık, kolektif hafıza ve bir takım semboller gibi temsiller ile ifade edilmektedir.

Bir yerin fiziksel, sosyal, kültürel, ekonomik ve anlama dair özellikleri birçok parametreden meydana gelmektedir ve bu parametrelerin birleşimi ile yerin özgün kimliği ortaya çıkmaktadır. Buraya kadar yapılan tanımlamalar neticesinde mahalle kimliğini oluşturan bileşenler Tablo 1'de özetlenmektedir.

\begin{tabular}{|c|c|c|}
\hline Fiziksel Kodlar & $\begin{array}{l}\text { Sosyal-Kültürel-Ekonomik } \\
\text { Kodlar }\end{array}$ & Anlam \\
\hline $\begin{array}{l}\text {-Doğal Çevre (İklim, Bitki } \\
\text { Örtüsü, Topografya, Hâkim } \\
\text { Rüzgâr Yönü vb.) } \\
\text {-Morfoloji (Ada-Parsel-Sokak } \\
\text { İlişkisi, Doku) } \\
\text {-Yapılı Öğeler (Binalar, Altyapı } \\
\text { Özellikleri) } \\
\text {-Biçimsel Özellikler } \\
\text {-Tipoloji/Mimari öğeler } \\
\text {-Malzeme kullanımı } \\
\text {-Yapım türü } \\
\text {-Sınırlar/Ölçek } \\
\text {-Odak/Kamusal Merkez }\end{array}$ & $\begin{array}{l}\text {-Sosyal İlişkiler (Sosyalleşme, } \\
\text { Yardımlaşma, Dayanışma vb.) } \\
\text {-Komşuluk } \\
\text {-Aktiviteler } \\
\text {-Kültürel Özellikler } \\
\text {-Değerler } \\
\text {-İnançlar } \\
\text {-Adetler } \\
\text {-Ritüeller } \\
\text {-Gelenek ve Görenekler } \\
\text {-Sembolik Ögeler } \\
\text {-Demografik Özellikler } \\
\text {-Politika } \\
\text {-Ekonomi } \\
\text {-Üretim } \\
\text {-Tarihi Doku }\end{array}$ & $\begin{array}{l}\text {-Aitlik } \\
\text {-Algı } \\
\text {-Aşinalık } \\
\text {-Kolektif Hafıza } \\
\text {-Ortaklık } \\
\text {-Yer duygusu } \\
\text {-Yere Bağlıık } \\
\text {-Semboller }\end{array}$ \\
\hline
\end{tabular}

Tablo 1: Mahalle Kimliği Bileşenleri (Altman ve Low, 1992; Alver, 2010; Alver, 2013;

Demirseren Çöl, 1998; Göregenli, Karakuş, Kösten ve Umuroğlu, 2014; Kutlu, Manav ve Ertürk, 2011; Özbek Eren, 2014; Özbek Eren, 2017; Relph, 1976; Tuan, 1997; Ujang, 2008)

\section{KONUT ÜRETIMINDE GÖREV ALAN KAMU KURUMLARININ KENTSEL KIMLIK KONULU YARIŞMALARINDAKI ÖDÜLLÜ PROJELERDE MAHALLE KURGUSUNUN INCELENMESI}

Kentlerde kimlik arayışının ülkemizdeki örneklerine bakıldığında son dönemde TOKİ Emlak Konut GYO A.Ş. tarafından düzenlenen "7 İklim 7 Bölge: Mahalle Ulusal Mimari ve Kentsel Tasarım Fikir Yarışması" ve İlbank tarafından düzenlenen "Mahalle Tasarımı Fikir Yarışması" projeleri dikkat çekmektedir. 2014 yılında "7 İklim 7 Bölge: Geçmişten Geleceğe" temasıyla yarışma düzenleyen ve buradan elde edilen sonuçlarla konut üretimine devam eden TOKi, 2017 yılında "mahalle" temasıyla tekrar yarışma düzenleyerek, buradan elde edilen sonuçların da ileride yapılacak olan uygulamalarda kullanılacağını belirtmektedir. Çalışma kapsamında ele alınan "7 İklim 7 Bölge: Mahalle Ulusal Mimari ve Kentsel Tasarım Fikir Yarışması" özgün mekânsal dokusu ve sosyo ekonomik özelliklerini kaybeden mahallenin günümüz kent ihtiyaçları doğrultusunda, şehircilik, kentsel tasarım, mimarlık ve peyzaj ilkeleri doğrultusunda kurgulanmasını amaçlamaktadır. Bu kapsamda yarışmacılardan mahalle dokusu, mahalle kültürü, sürdürülebilirlik, kimlik, insan/kullanıcı odaklılık, yaşam ve mekân kalitesi, sosyal yaşam, geleneksel değerler, modern yaşam gereksinimleri, sosyal bütünleşme, mimari öğeler, kentsel estetik ve peyzaj, siluet, ekoloji kavramları ile yeni 
şehircilik akımlarının mahalle ortak bileşeninde sentezlenmesi beklenilmiştir. Yarışma alanları ileride Türkiye'deki her bölgede uygulama yapılması planlandığı alanlar arasından belirlenmiş, her alan için parsel alanı, minimum hane sayısı ve merkeze uzaklık mesafeleri verilerek ekiplerin çalışma alanlarını kendilerinin belirleyeceği belirtilmiştir. Buna göre çalışma alanları Akdeniz Bölgesi (Hatay/Dörtyol), Doğu Anadolu Bölgesi (Muş/Kepenek), Ege Bölgesi (Denizli/Pamukkale), Güneydoğu Anadolu Bölgesi (Mardin/Artuklu), İç Anadolu Bölgesi (Eskişehir/Odunpazarı), Karadeniz Bölgesi (Kastamonu/Merkez Örencik), Marmara Bölgesi (Tekirdağ/Çorlu) olarak belirlenmiştir (URL 3).

Çevre ve Şehircilik Bakanlığının "Şehir 2023" çalışmaları kapsamında İlbank tarafından düzenlenen "Mahalle Tasarımı Fikir Yarışması"nın amacı; tarihi, doğal, sosyo-kültürel bağlam içerisinde, mahallenin geleneksel değerlerle birlikte mekânsal kurgusu ve sosyal ilişkilerinin yeniden özgün bir şekilde yorumlanması ve kentsel ihtiyaçlara çözüm sunacak planlama, kentsel tasarım, mimari ve peyzaj düzenleme ilkelerinin elde edilmesi olarak belirlenmiştir. Bu doğrultuda yarışmacılardan; mahalle, sokak, meydan, park vb. kamusal mekânlarda kaybolmaya yüz tutan işlevlerin, dayanışma, paylaşma, öğrenme, birlikte üretme gibi sosyal kavramların yeniden canlandırılmasını sağlayacak mekânların ve kente olumlu katkı sağlayacak kimlikli bir mahallenin kurgulanması, açık, yarı-açık, kapalı alanlar ile hem işlevsel hem de mekânsal düzenin kurgulanması, insan ölçeği, yaya erişimi ve karma kullanımın esas alınması, geleneksel değerlere ait yaşam tecrübesi sunulması, kentsel doku mirasına ait izler ile özgün mimari ve kent dinamiklerinin esas alınması, sosyolojik ve fiziksel gereksinimleri karşılayan yeterli konfora sahip olması, komşuluk ilişkilerinin, sosyal ve kültürel ilişkilerin yeniden ele alındığı, tarihi ve doğal yapıyla uyumlu özgün bir tasarım dili oluşturulması, sürdürülebilirliğin temel alındığı, enerji etkin yaklaşımların üretilmesi beklenilmiştir. Yarışma alanı olarak farklı coğrafi bölgelerden seçilen Bursa, Çanakkale, Samsun, Kayseri, Konya, Erzurum, Gaziantep, Diyarbakır, Adana, Aydın ve Rize illeri belirlenmiştir (iller Bankası A.Ş., 2017b).

"7 İklim 7 Bölge: Mahalle Ulusal Mimari ve Kentsel Tasarım Fikir Yarışması" sonucunda yedi bölge için ayrı derecelendirilme yapılmış olup her bölge için birincilik, ikincilik, üçüncülük ödülü ve üç mansiyon derecesi belirlenmiştir. Yarışma sonucunda Güneydoğu Anadolu Bölgesinde birinci ödül ve üçüncü mansiyon, l̇ç Anadolu Bölgesinde birinci, ikinci ve üçüncü ödüller ile Marmara Bölgesinde birinci ve ikinci ödüller verilmemiştir. "Mahalle Tasarımı Fikir Yarışması"nda ise üç proje eşdeğer ödül alırken beş proje mansiyon almıştır. Böylece "7 İklim 7 Bölge: Mahalle Ulusal Mimari ve Kentsel Tasarım Fikir Yarışması"nda derece alan otuz beş proje ile "Mahalle Tasarımı Fikir Yarışması"nda derece alan sekiz projenin raporları ve sunum paftaları üzerinden mahalle kurgusunun fiziksel, sosyal ve anlam boyutlarında nasıl ele alındığı incelenmiştir. Ancak makale kapsamında hepsine yer verebilmek mümkün olmadığı için her bir bölgeden projelerin olmasına özen gösterilerek otuz bir projeye ilişkilendirilen kimlik kodları altında yer verilmiştir. Mahalle kurgusunu oluşturan parametreleri içeren bu projelerde bir önceki bölümde değinilen parametrelerin nasıl ele alındığı ve mekânsal kurguya nasıl yansıtıldığı incelenmiş ve sonucunda bir takım anahtar kavramlar elde edilmiştir.

\subsection{Fiziksel kodlar:}

\subsubsection{Doğal çevre (topografya, iklim, bitki örtüsü vb.)}

Yarışma alanları Türkiye'nin farklı iklim ve coğrafi özelliklere sahip yedi coğrafi bölgesinden belirlendiğinden proje girdilerinde seçilen alanların coğrafi (doğal) özelliklerinin dikkate alındığı ve buna bağlı olarak topografya kullanımı, yakın çevreyle 
ilişki, yerel bitki türlerinin kullanımı, iklimsel özellikler, hâkim rüzgâr yönü gibi verilerin tasarım kararlarında yer aldığı görülmektedir.

Bu bağlamda 7 Iklim 7 Bölge: Mahalle Yarışması'nda; Ege Bölgesi (Denizli) 2. Ödül alan projede alanda mevcut olan eğime göre şekillenmiş yol izleri sürdürülmüş ve topografya ile birlikte hareket eden küçük yapı blokları düşünülerek araziyle uyumlu siluet oluşturulmuştur (URL 4). Eğimli arazi koşullarına sahip Karadeniz Bölgesinde (Kastamonu) 1. Ödül alan projede topografyanın yüksek kısımları mahallenin her noktasından algılanabilmesi için kamusal fonksiyonlara ayrılmıştır. Böylelikle geleneksel mahalle dokusunda da görülen dini yapı kompleksi ve kültür kompleksi mahalle kimliğine vurgu yapılacak şekilde en yüksek noktalarda konumlandırılmıştır (URL 5). Makro serender kurgusunun oluşturulduğu Karadeniz Bölgesi (Kastamonu) 3. Ödül alan projede alandaki mevcut eğim izleri ile baza seperasyonu yapılarak özel yaşam ile kamusal yaşam sınırı çizilmiştir (URL 6). İç Anadolu Bölgesi (Eskişehir) 3. Mansiyon alan projede Eskişehir'in flora açısından zenginliği kullanılarak, botanik bahçeler ve yeşil alanlar ile yerel floranın mahalle kapsamına yayılması düşünülmüştür (URL 7).

Mahalle Tasarımı Fikir Yarışması'nda; Rize'de yapılan çalışma ile mansiyon alan projede de makro serender kurgusu yapılarak zorlu topografya şartlarının kontrol altına alındığı belirtilmiştir (Şekil 1) (URL 8).
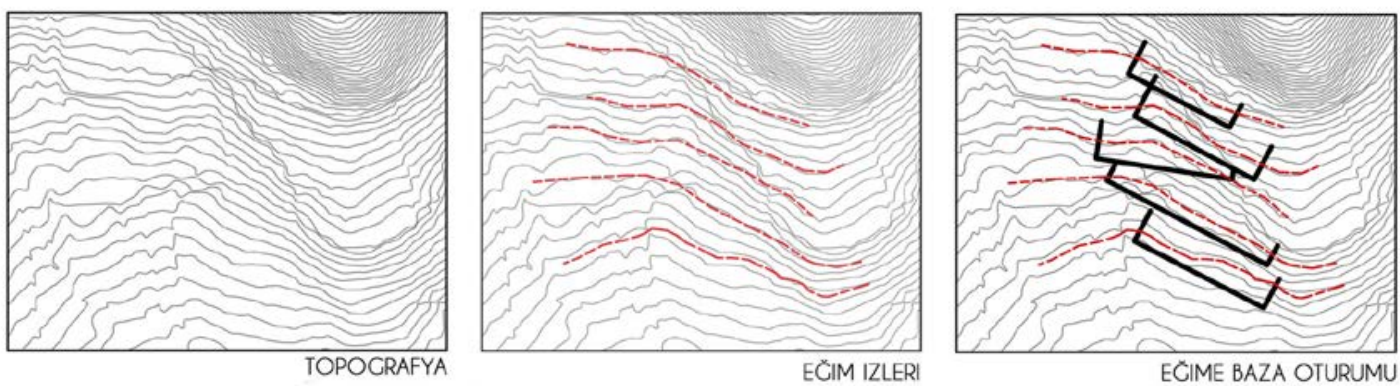

Şekil 1: Topografya Uyumu - Mahalle Tasarımı Fikir Yarışması (Rize) (URL 8).

\subsubsection{Morfoloji}

7 Ílim 7 Bölge: Mahalle Yarışması'nda; seçili proje alanları üzerinde mevcut yapı dokusu bulunmasa da bazı derece alan projelerde bölgede yer alan yakın yerleşim yeri dokusu ya da tarihi dokunun tasarımda kullanıldığı görülmektedir. Örneğin Akdeniz Bölgesinde (Hatay) 3. Mansiyon alan projede Antakya'nın Antik kent dokusu düşünülerek Hippodamos tarzı plan olarak adlandırılan ızgara plan dokusu belirleyici kimlik öğesi olarak tasarımda kullanılmıştır (URL 9). Doğu Anadolu Bölgesi (Muş) 2. Ödül alan projede tarihi Kale bölgesinde gözlemlenen çarşının oluşumunda fiziksel belirleyici olarak rol oynayan sıra evler tasarımın ilkesel kararlarının oluşturulmasında referans alınmıştır (URL 10). Ege Bölgesi (Denizli) 1. Ödül alan projede Denizli ile ilgili yerel mahalle kurgusuna örnek teşkil edecek Buldan İlçesi gösterilerek, Buldan'ın "girift" yapısının tasarıma yön verecek yerel ve tarihi verileri tasarıma aktarıımıştır (Şekil 2) (URL 11). 


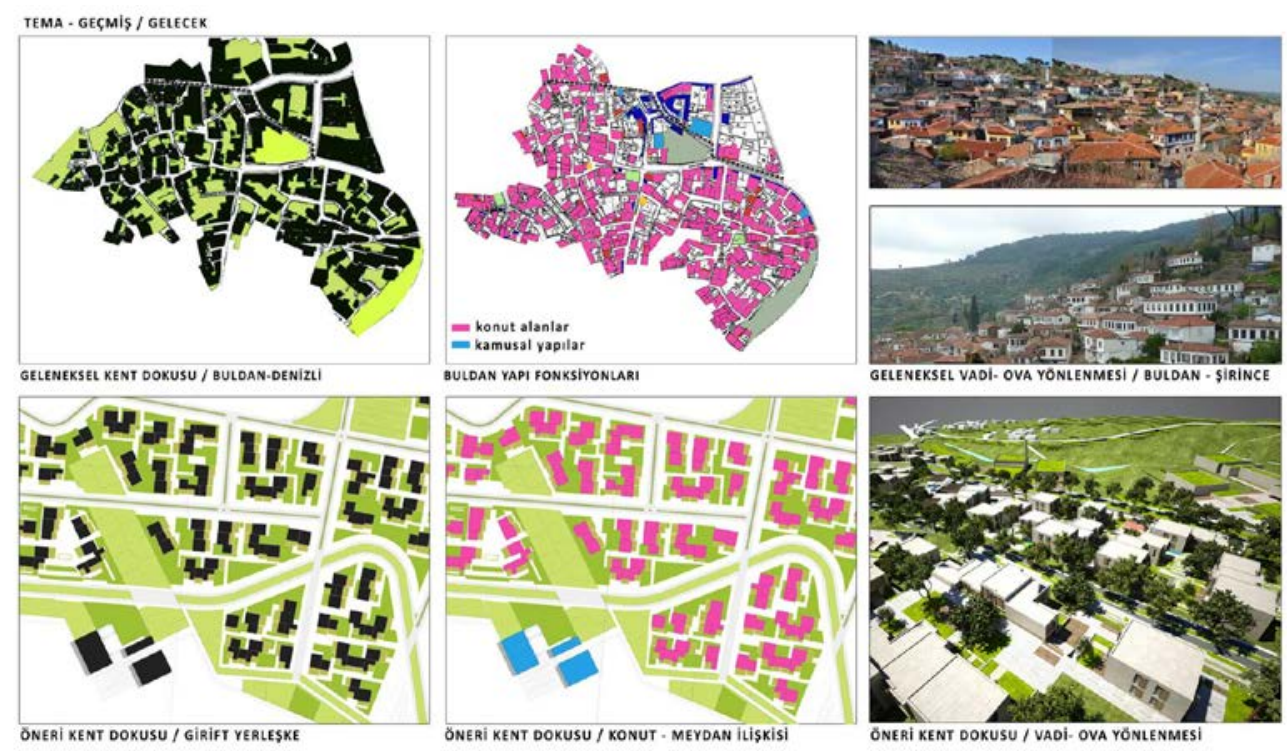

Şekil 2: Kent Dokusu - Ege Bölgesi (Denizli) 1. Ödül (URL 11).

Ege Bölgesi (Denizli) 1. Mansiyon alan projede kent kimliğinin Hierapolis Antik kentinin izleriyle kurgulandığı belirtilmiştir. Hierapolis Antik kentinde gözlemlenen ızgara kent planı ve bu planda konut bölgesiyle sosyal donatıların birbirlerinden ayrılmasını sağlayan ve üzerinde kilise, hamam, ticari agora, gymnasium gibi birimlerin yer aldığı ana akstan yola çıkılarak kentin ticaret ve sosyo-kültürel donatılarını çevresinde toplayan bir "etkileşim aksı" oluşturulmuştur (URL 12).

Karadeniz Bölgesi (Kastamonu) 1. Ödül alan projede topografyayı takip eden çıkmaz sokak kurgusu oluşturularak geleneksel mahallede olduğu gibi kendi özel alanı yaratılan etkileşim alanları tasarlanmıştır. Aynı zamanda çıkmaz sokaklar adını aldığı peyzaj bahçelerine bağlanmıştır (Şekil 3) (URL 5).

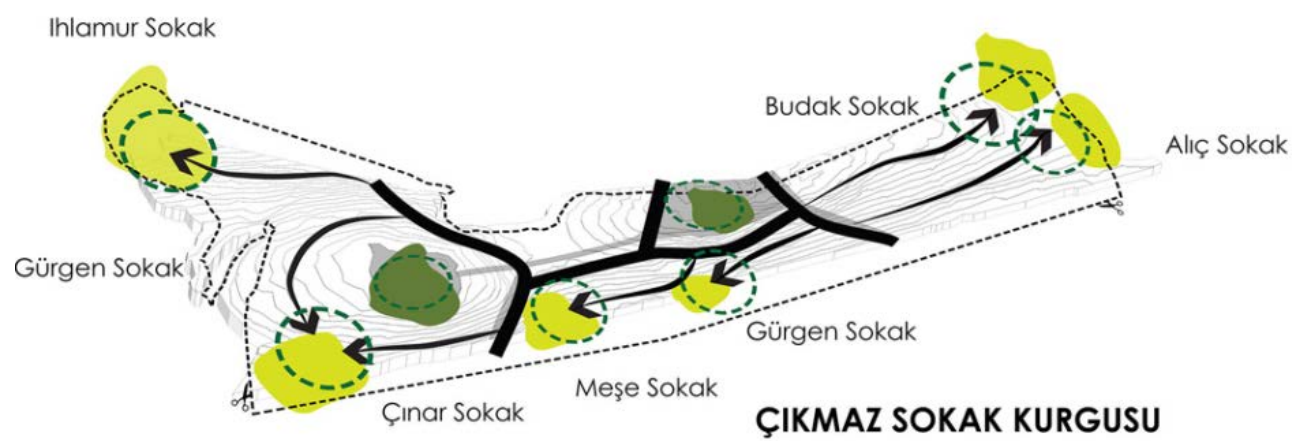

Şekil 3: Çıkmaz Sokak Kurgusu - Karadeniz Bölgesi (Kastamonu) 1. Ödül (URL 5).

\subsection{3. Ölçek/Sınırlar}

Günümüzde yapı ölçeklerinin büyümesiyle birlikte ulaşım akslarının da ölçeği büyümekte ve sokaklar taşıtların hâkim olduğu, insan etkileşiminin azaldığı taşıt yollarına dönüşmektedir. Bu nedenle "ölçek" kavramı mahalle kurgusunda anahtar kavramlardan biri olarak yer almaktadır. Yarışma projelerinde de görüldüğü üzere mahalle kurgusunda ölçeğin kontrol altında tutularak insanların birbiri ile iletişime geçebileceği "insan ölçeğinde/yaya odaklı" mekânlar sunulması hedeflenmektedir. Bunun için yayalara özel sokak kurguları yapıldığı ya da taşıt yollarının tamamen 
mahalle çeperinde tutularak, mahalle içerisinde yer alan birimlere yaya olarak erişebilirliğin sağlandığı ve binaların kat yüksekliklerinin belirli oranda tutularak sokakla kurulan ilişkinin kuvvetlendirildiği görülmektedir.

7 Íklim 7 Bölge: Mahalle Yarışması'nda; Doğu Anadolu Bölgesi (Muş) 1. Ödül alan projede mahalle ölçeğinin belirlenmesinde sosyo-kültürel odaklar ve kamusal açık alanların oranı ile insan yoğunluğunun ilişkilendirilmesi sonucunda sosyal alanların daha yaşanabilir olması düşünülmüştür (URL 13). Doğu Anadolu Bölgesi (Muş) 3. Ödül alan proje ekibi insan ölçeğinde tasarım yaparak 400 m mesafede 5 ile 10 dakikalık yürüyüş ile ulaşılabilen odak noktaları tasarlamıştır. Mahalle içinde yaya dolaşımı ön planda tutularak araç yolu yerleşim yerinin çeperinde düşünülmüştür (Şekil 4) (URL 14). Akdeniz Bölgesi (Hatay) 1. Mansiyon alan projede kütle konumlandırmaları ve kademelendirmelerinde insan ölçeği, göz seviyesinde mekân algısı ve ara mekânların kurgulanması göz önünde bulundurulmuştur. Dört komşuluk birimi tasarlanarak bu birimlerin içerisine de küçük komşuluk birimleri yerleştirilmiştir. Ana omurga ağaçlıklı gezinti yolu olarak yaya ve bisiklet ağırlıklı olarak düzenlenirken yavaşlatılmış araç trafiğine açık şekilde tasarlanmıştır (Şekil 5) (URL 15). Karadeniz Bölgesi (Kastamonu) 1. Mansiyon alan projede mahallenin çevresiyle erişilebilir olması için araç yollarının mahalle çevresinde sınır oluşturmasının engellenmesi düşünülerek "serbest sınır" tasarım ilkesi olarak belirlemiştir (URL 16).

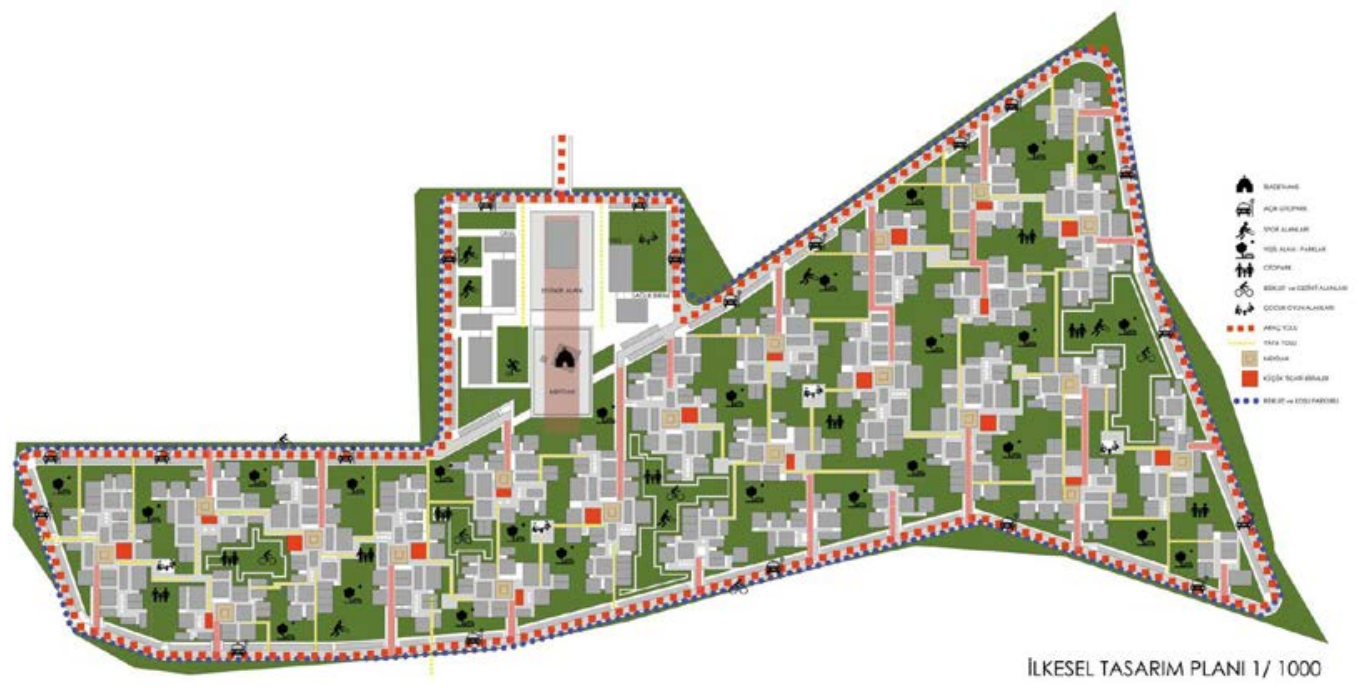

Şekil 4: İlkesel Tasarım Planı - Doğu Anadolu Bölgesi (Muş) 3. Ödül (URL 14).

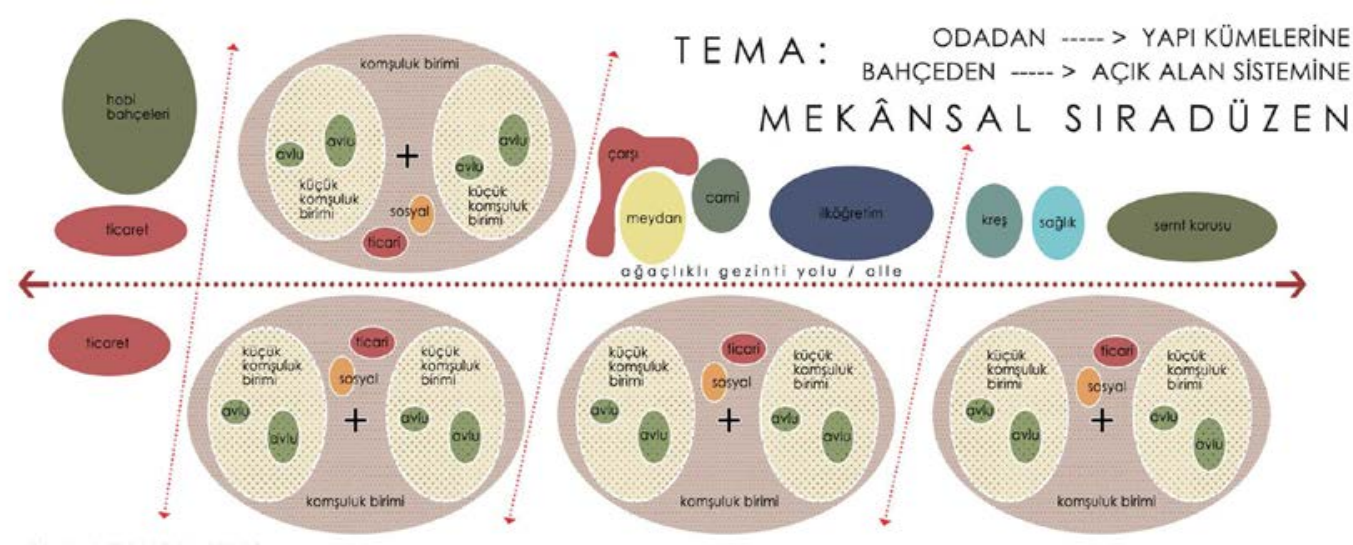

Şekil 5: Tematik Kavramsal Şema - Akdeniz Bölgesi (Hatay) 1. Mansiyon (URL 15). 
İç Anadolu Bölgesi (Eskişehir) 3. Mansiyon alan projede kentlinin kullanımına açık kamusal mekânların engelliler için de kolay erişilebilir ve kullanılabilir olması için mevcut topografyanın yardımıyla zeminde seviye farklılıklarının minimuma indirilmesi hedeflenmiştir ve gerektiği durumlarda rampa kullanımı ile seviye farklııklarına çözüm getirilmiştir (URL 7).

\subsubsection{Odak/ kamusal merkez}

Mahalle meydanı geleneksel anlamıyla cami, çay bahçesi, temel ihtiyaç birimlerinden oluşan ticaret birimleri ile anılmakta olup mahallelinin birbirleriyle en çok iletişime geçtiği yer olarak kabul edilmektedir. Yarışma projelerinde mahallenin odak noktasını kamusal birimlerin yer aldığı meydan, alt meydan ya da yayalaştırılmış akslar ile oluşturulduğu görülmektedir. Buluşma, karşılaşma ve günlük ihtiyaçların karşılanması için odak noktaları tasarlanmıştır. Odak noktalarında; ticaret alanları, kültür merkezi, kütüphane, mahalle evi, eğitim, sağlık ve dini tesis birimlerinin yer aldığı ve bu birimlerin sosyal donatı alanları ile ilişkilendirildiği görülmektedir.

7 Iklim 7 Bölge: Mahalle Yarışması'nda; Ege Bölgesi (Denizli) 1. Ödül alan projede yaya akışının yaya yolları, meydanlar ve açık amfiler ile sistemli ve düzenli bir şekilde kamusal, yarı kamusal ve özel alanlara hiyerarşik olarak dağıtılması önerilirken (URL 11), Ege Bölgesi (Denizli) 3. Mansiyon alan projede fonksiyonların odak noktasında öbekleşmesi yerine mahalle içinde dağıtılarak sokak aralarına saçılması önerilmiştir (URL 17). Odak noktaları iki kurguda farklı şekilde ele alınsa da her ikisinde de "yaya odaklı" kurgunun oluşturulması amaçlanmıştır.

\subsubsection{Karşılaşma mekânları}

Mahallede sosyal etkileşimi arttıracak mekânlar sosyal kodlarla ilişkili olarak fiziksel boyutta tasarlanmaktadır. Bölgelere özgü geleneksel toplanma alanları ya da aktivitelere, ritüellere göre işlevlendirilen diğer mekânlar karşılaşma mekânlarını oluşturmaktadır.

Yarışmalarda derece alan projelerde meydan, avlu, dar gölgeli sokaklar, geleneksel dokuda hayat olarak adlandırılan kat bahçeleri (Akdeniz Bölgesi 1. Mansiyon, URL 15), abbaralar (Güneydoğu Anadolu Bölgesi 1. Mansiyon, URL 18), buluşma köşeleri, çıkmaz sokaklar, bahçeler, yeşil koridor, taşlık (Karadeniz Bölgesi 2. Mansiyon, URL 19), gezemek (Diyarbakır, Eşdeğer Birincilik Ödülü, URL 20), kapı önü mekânları, çeşme başları, mahalle kestirmeleri gibi makrodan mikro ölçeğe kamusal alanlar ve bunlar arasında geçiş sağlayan bağlantılar ile farklı mekânsal kurgular yapıldığı görülmektedir (Şekil 6). 


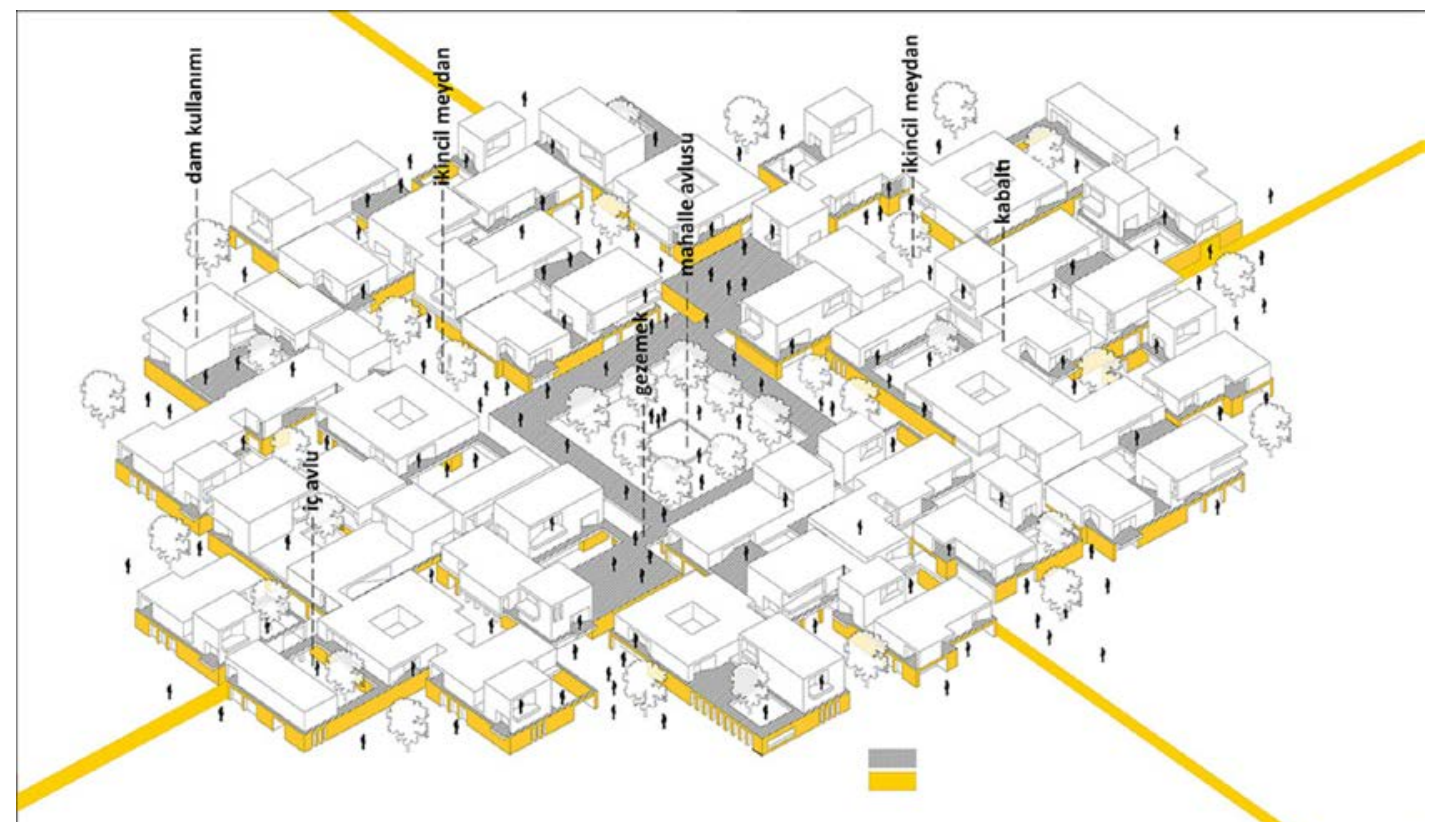

Şekil 6: Karşılaşma Mekânları-Mahalle Tasarımı Fikir Yarışması: Diyarbakır Örneği (URL 20).

\subsubsection{Biçimsel özellikler}

Bina ve sokak tipolojileri, mimari öğeler, malzeme türleri, yapım tekniği gibi biçimsel özelliklerin mevcut dokuya uygun olarak tasarlanması ile yerel kimliğin sürdürülmesine olanak sağlanırken, aynı zamanda bölgede daha önce kullanılan biçimsel özellikler ile kullanıcılar için aşinalığın oluşturulması hedeflenmektedir.

7 Iklim 7 Bölge: Mahalle Yarışması'nda; Güneydoğu Anadolu Bölgesi 1. Mansiyonu alan projede avlu, dar sokak, teras, dam ve abbara kurgusu yapılmıştır. Mevcut dokuda avlu kurgusuyla mekân ilişkisinin ayrımını tanımlayan revaklar ile eski Mardin kent dokusunda görülen üstünde konut bölümünün yer aldığı geçitler olan abbaralar projede yeniden yorumlanarak tasarıma aktarılmıştır (Şekil 7 ve 8) (URL 18).

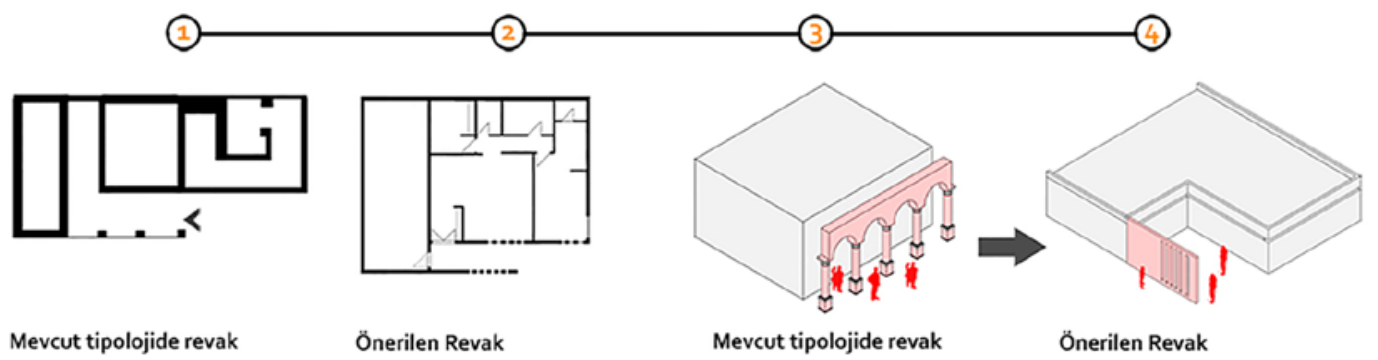

Şekil 7: Revak Yorumu - Güneydoğu Anadolu Bölgesi (Mardin) 1. Mansiyon (URL 18). 


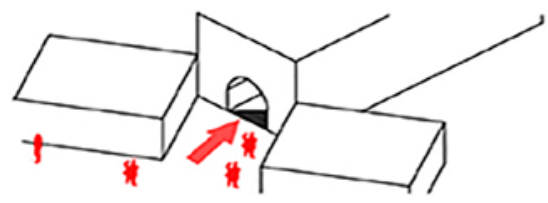

Mevcut tipolojide abbara(geçit)

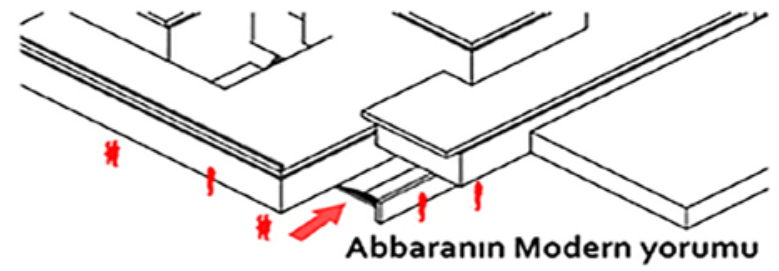

Abbaranın Modern yorumu

Şekil 8: Abbara Yorumu - Güneydoğu Anadolu Bölgesi (Mardin) 1. Mansiyon (URL 18).

Ege Bölgesi (Denizli) 2. Mansiyon alan projede yapılarda çıkma yapılarak mekânda büyüme sağlanırken cumbaya atıf yapılmış ve içe dönük yaşantının sokakla iletişimi sağlanmaya çalışılmıştır (URL 21).

Karadeniz Bölgesi (Kastamonu) 1. Ödül alan projede; konut tipleri tasarlanırken Türk evi plan tipleri incelenerek sofaların eyvan ve odalar ile kurduğu ilişkiler üzerinden şemalar oluşturulmuş ve işlevselliğini kaybetmeden günümüz konut kullanım koşullarına uygun olarak yeniden yorumlanmıştır. Projede geleneksel konutta göze çarpan en önemli mimari öğenin sokakla ilişki kuran cephe çıkmaları olduğu belirtilmiştir. Bu çıkmaların iç mekân kurgusunda önemli rol oynayan sofa ve eyvanların dışa vurumu olduğu belirtilerek eyvan kurgusu ile hane halkının bir arada vakit geçirebileceği yaşam alanları oluşturulmuştur (Şekil 9 ve 10) (URL 5).
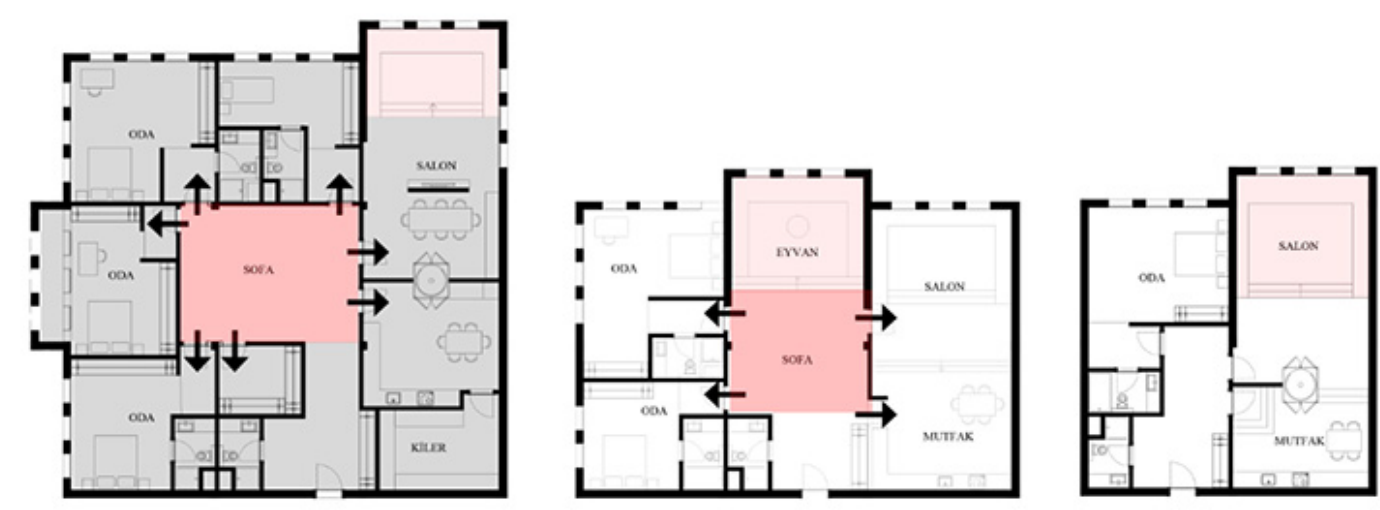

Şekil 9: Plan Tipi Örnekleri - Karadeniz Bölgesi (Kastamonu) 1. Ödül (URL 5).

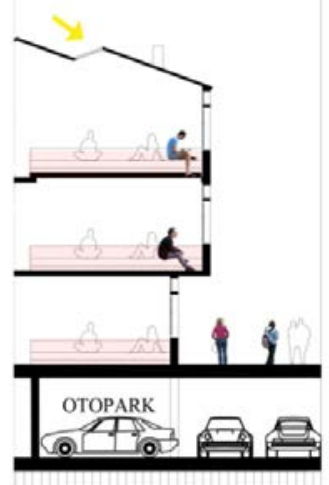

Şekil 10: Eyvan ve Sokak Illişkisi - Karadeniz Bölgesi (Kastamonu) 1. Ödül (URL 5). 
Karadeniz Bölgesi (Kastamonu) 2. Mansiyon alan projede geleneksel yapı dokusunda görülen taş ve ahşap malzemeleri kullanılarak taş bir baza üzerinde ahşap ağırlıklı yapı tipolojisi tasarlanmıştır (URL 19). Ege Bölgesi (Denizli) 3. Ödülü alan projede cephe malzemesi olarak bölgede üretilen traverten seçilmiştir (URL 22).

Marmara Bölgesi (Tekirdağ) 3. Ödül alan projede şekilsel özellikler kullanarak bir bağlam oluşturulmasından çok anlam bağlamında geleneksel birikimlerden faydalanılarak günümüz intiyaçlarına yanıt aranması gerektiği belirtilmiştir. Bununla birlikte cephe tasarımlarında geleneksel mimariden ahşap, tuğla gibi malzemeler; cumba, panjur gibi mimari öğeler referans alınmıştır (URL 23).

\subsection{Sosyal, kültürel ve ekonomik kodlar}

Bir yerde yaşayan topluluğun sahip olduğu özellikler o yeri hem sosyal hem de mekânsal açıdan biçimlendirmektedir. Bu nedenle mahalleli, bu başlık altında yer alan tüm kavramların anahtarıdır. İnsanların eylemleri, birbirleriyle olan ilişkileri, inançları, ortak değerleri, amaçları fiziksel çevreleri ile etkileşim halinde olup yer kimliğinin belirlenmesinde rol almaktadır. Aynı durum tersi içinde geçerlidir. Çevresel özellikler de sosyal boyuta kimlik kazandırmaktadır. Yöresel özelliklerden çıkarılan sosyal kodların mekânları fiziksel boyutta biçimlendirdiği görülmektedir.

7 Iklim 7 Bölge: Mahalle Yarışması'nda; Akdeniz Bölgesi (Hatay) 3. Ödül alan projede hane ölçeğinde mahremiyet sağlanırken, ortak alanlarda komşuluk ölçeğinde yere özgü imece uğraşların, düğün gibi kültüre özgü geçici etkinliklerin yapılabilmesine olanak sağlanması amaçlanmıştır (Şekil 11) (URL 24).
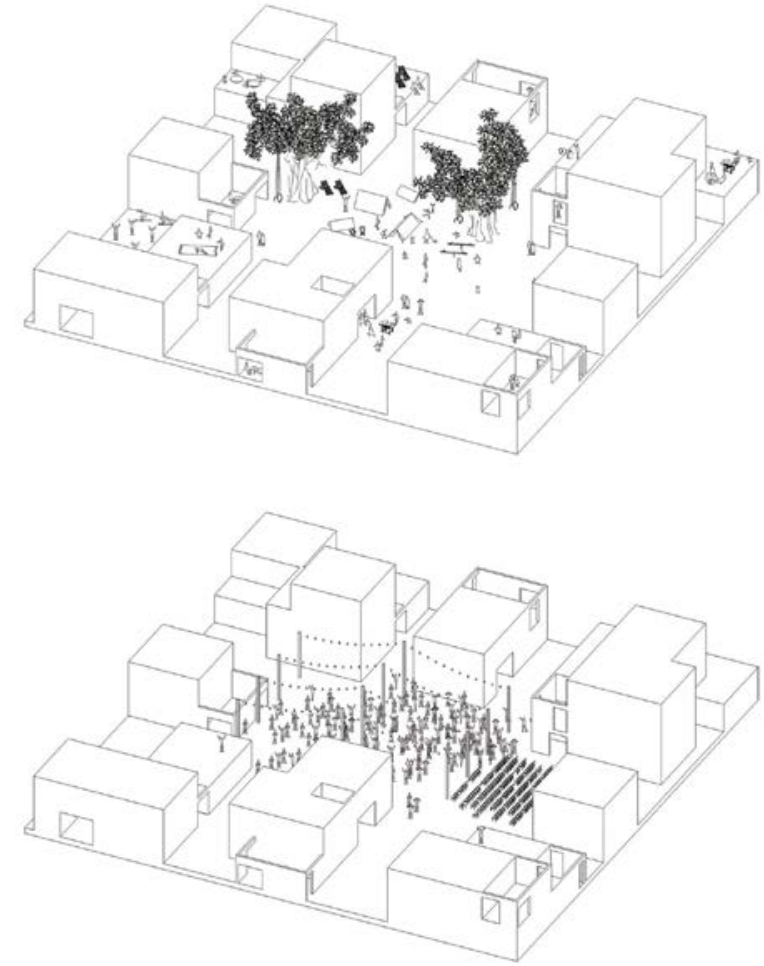

Şekil 11: Ortak Alan Kullanımları - Akdeniz Bölgesi (Hatay) 3. Ödül (URL 24).

Akdeniz Bölgesi (Hatay) 1. Mansiyon ödülü alan projede kentsel mikroekonominin desteklenmesi ve kadınların ev içi üretimlerini taşıyabilecekleri mekânların oluşturulması amaçlanmıştır. İlçenin ana istihdam alanlarından birinin tarım olması 
nedeniyle ekonomik katkı ile toplumsal kaynaşma ve dayanışmayı geliştiren hobi bahçeleri ya da kentsel tarım alanı olarak kullanılabilecek rekreatif alanların planlanması ile yazlık sinema, halk eğitimi gibi kültürel işlevlere uygun mekânlar tasarlanması düşünülmüştür (URL 15).

Doğu Anadolu Bölgesi (Muş) 1. Ödül alan projede komşuluk ilişkileri, yakınlık, birlik kurma, aidiyet, dayanışma, müşterek üretim, öğrenme, paylaşma, bütüncüllük, güvenli hissetme duygularının sağlanması amacıyla sokak arasında gerçekleştirilen düğün ve sünnet etkinliklerinin sürdürülmesi, mahalle kadınlarının evleri önünde komşularıyla sohbet edip el işlerini birlikte üretmesi düşünülmüştür. Havuş ${ }^{4}$ içerisinde tandırlık bölümü tasarlanarak Muş geleneklerinde görülen birlikte yaşam ve birlikte üretime katkı sağlanması amaçlanmıştır. Muhtarlık, mahalleli etkileşim ve yardımlaşma merkezi, büyükler okulu (okuma-yazma), yaşlı bakım birimi, mahalle tiyatro ve sineması, karakol, itfaiye, mahalle ilkokulu ve kreşi gibi birimler eyvan kurgusuna takılarak mahallelinin karşılaşma, selamlaşma ve etkileşim alanlarının arttırılması amaçlanmıştır (URL 13).

Doğu Anadolu Bölgesi (Muş) 3. Mansiyon alan projede "mahalle avlusu" kurgusunda sosyal ve kültürel etkileşimin sağlanacağı bir merkez oluşturularak, şenlik, düğün, cenaze gibi merasimlerin geleneksel biçimde gerçekleştirilebileceği, ayrıca uçurtma uçurma, ip atlama, yakan top gibi unutulmaya yüz tutmuş çocuk aktivitelerinin yapılabileceği geniş alanlar önerilmiştir. Projede bölgeye özgü kışlık ürünleri kurutma aktiviteleri için teras çatılara yer verilmiştir (URL 25).

Ege Bölgesi (Denizli) 1. Mansiyon alan projede alanın turizm bölgesinde yer alması nedeniyle konut dokusu içine butik turizm tesisleri eklenmiştir (URL 12).

Güneydoğu Anadolu Bölgesi (Mardin) 2. Ödül alan projede "sosyo-kültürel etkinlik alanı" olarak düşünülen alanın çeşitli toplantı, sergi, kurs vb. amaçlı kullanılabileceği gibi geleneklerin devamlılığını sağlayan salça, reçel, zeytinyağı yapımı gibi ortak aktiviteler için ve mahalle sakinlerinin özel günlerinde muhtar izniyle taziye kabulü, mevlit vb. amaçlar için de kullanılabilmesi düşünülmüştür. Bu projede bölgenin farklı inançlara ev sahipliği yapıyor olması sebebiyle tasarıma kilise de eklenmiştir (URL 26).

Güneydoğu Anadolu Bölgesi (Mardin) 1. Mansiyonu alan projede "zanaat kültürü" için dokumacılar meydanı, bakırcılar meydanı gibi zanaat meydanları oluşturulmuştur. Ayrıca şenlik, konser, açık hava sineması etkinlikleri için çok amaçı etkinlik meydanı kurgusu yapılmıştır. Kotların sunmuş olduğu bir fonksiyon olarak mahalle ekim alanlarında her mahallelinin kendi ürününü yetiştirmesiyle üretim bilincinin oluşturulması düşünülmüştür. Tasarım kurgusundaki damların sebze ve meyve kurutma alanı olarak kullanılması ve Mardin yöresine has kuş yetiştirme kültürünün de mahalle kültürüne dâhil olması kurgulanmıştır (Şekil 12) (URL 18).

\footnotetext{
${ }^{4}$ Doğu Anadolu Bölgesi'ne özgü "havuş" bahçe-avlu görevi gören Geleneksel Doğu Anadolu evi ortak mekânıdır (URL 13).
} 

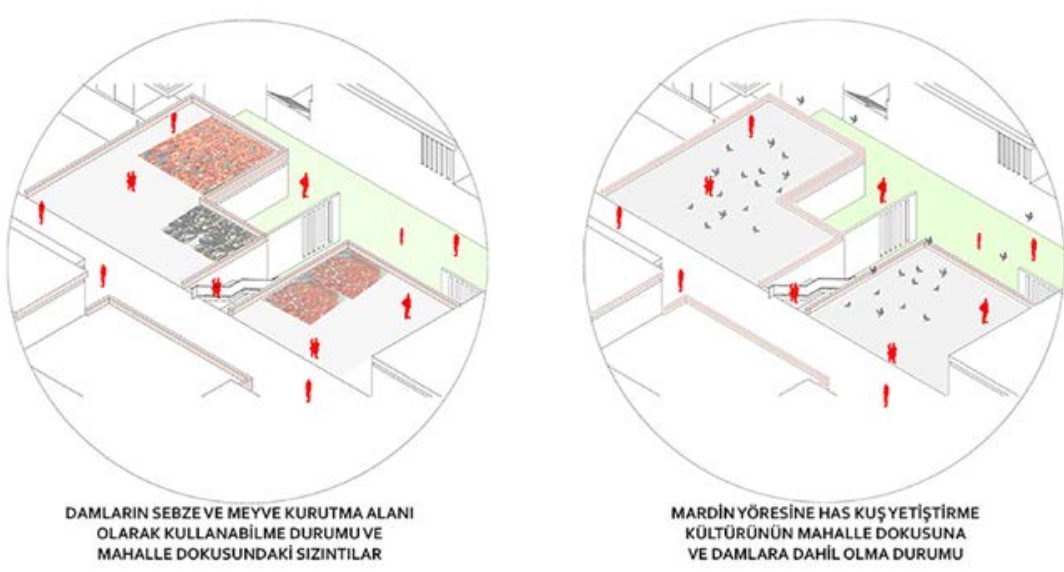

Şekil 12: Damda Sebze ve Meyve Kurutma/Kuş Yetiştirme-Güneydoğu Anadolu Bölgesi 1. Mansiyonu (URL 18).

Karadeniz Bölgesi (Kastamonu) 2. Ödül alan projede mahalle bostanı ile permakültür gibi hem üretim hem de ekoloji odaklı yaşam pratiklerinin desteklenmesi ve mahallelinin üretim kanallarına yönlendirilerek üretimin mahallenin bir parçası olması amaçlanmıştır (URL 27). Benzer şekilde Karadeniz Bölgesi (Kastamonu) 3. Ödülü alan projede de parmakültür kurgusu ile topraktan gelen ürünlerin ticari faaliyete dönüştürülmesi amaçlanmıştır (URL 6).

Mahalle Tasarımı Fikir Yarışması'nda; Adana'da yapılan çalışma ile eşdeğer ödül alan projede "sokakta olmak" fikrinden yola çıkılarak çocukların komşuluk ilişkileri ve oyun oynama alışkanlıklarını deneyimlemesi amaçlanmıştır (URL 28). Bursa'da yapılan çalışma ile eşdeğer ödülü alan projede farklı aile büyüklükleri, kültürel özellikler ve farklı gelir gruplarının bir arada yaşayabileceği esnek mekânların oluşturulması tasarım ilkesi olarak belirlenirken, yaşayan ve güvenli sokak kurgusuna değinilmiştir (URL 29). Gaziantep'te yapılan çalışma ile mansiyon alan projede yapı birimlerinin balkon, cumba ve geniş görüş açılarıyla tasarlanması ile kullanıcıların güvenliklerini kendilerinin sağlayabileceği bir ortam oluşturulması amaçlanmıştır (URL 30).

\subsection{Anlam}

Kişilerin yer ile kurduğu bağ ile gelişen aitlik duygusu, kolektif hafıza, aşinalık, algı, ortaklık, yaşam biçimi kavramları anlam başlığı altında ele alınmaktadır. Bir yerin kimlik kazanması ya da var olan kimliğini sürdürebilmesinde sakinlerinin kendilerini o yere ait hissetmesi önemlidir. Bu bağlamda bazı yarışma projelerinde bu kurgunun da tasarıma yansıtıldığı görülmektedir.

7 Íklim 7 Bölge: Mahalle Yarışması'nda; Akdeniz Bölgesi (Hatay) 2. Ödül alan projede mahalledeki düşük gelirlilere katkı sağlama ve kaynaşma için "mahalle anneliği" gibi sosyal sorumluluk projeleri geliştirilmesi, kooperatifler aracılığıyla mahallelinin birlikteliği, yerel esnaf ve yerel üretimin desteklenmesi önerilmiştir. Ayrıca oluşturulan senaryoda proje alanının 4 etaplık bir inşaat süreci sonucunda mahalle kimliğine kavuşacağı öngörülmüştür (URL 31). Akdeniz Bölgesi (Hatay) 3. Ödül alan projede yere bağlılık için insan odaklı mekânsal ölçek kurgusu yapılması ve yere/yerele özgü eylemlerin (gelenek ve görenekler, ritüeller, yerel günlük aktiviteler) kullanıcı ve mekân arasında bağ oluşturması amaçlanmıştır (URL 24). Mahalle denildiğinde bellekte yer eden unsurların mekân kurgusu içinde düşünülerek aidiyetliğin ve kentsel belleğin canlandırılması amacıyla Akdeniz Bölgesi (Hatay) 3. Mansiyon alan projede avlu 
kurgusu yapılmıştır (URL 9). Aynı şekilde Doğu Anadolu Bölgesi (Muş) 1. Ödül alan projede havuşta ortak yaşamın getirdiği güven duygusu ve bağlılık ile aidiyet duygusu yüksek bir mahalle oluşturulması kurgulanmıştır (URL 13). Doğu Anadolu Bölgesi (Muş) 3. Mansiyon alan projede bellek öğesi olarak çınaraltı parkı ve meydan camisine yer verilmiştir (URL 25). Güneydoğu Anadolu Bölgesi (Mardin) 3. Ödül alan projede yapı yüzlerinde yerel taş yüzeyler kullanılması ile aşinalık ve aidiyet duygusunun geliştirilmesi amaçlanmıştır (URL 32).

Doğu Anadolu Bölgesi (Muş) 1. Ödül alan projede mahalle deneyiminin ön planda tutulması ve mahalle içinde anlamlı bir örüntü oluşturulabilmesi için bütüncül yaklaşım ile anlama, anlamlandırma, duyarlılık/içselleştirme, eleştirel bakış/sorgulama, yaşantı/deneyim, eylemek/eylemsellik, sezgisellik, özgüllük, iletişim, aidiyet, izlenim gibi çok yönlü derin anlamları barındırması gerektiği belirtilerek, mahalleye bağlıı̆̆ın sağlanması için mahalle ölçeğinin belirlenmesinde mahallelinin kendilerini ait hissedebilecekleri, neredeyse tüm yaşayanları bireysel olarak tanıyabilecekleri ve etkileşimde bulunabilecekleri kapasitelerde fiziksel bölgelendirmeler yapılması amaçlanmıştır (URL 13). Güneydoğu Anadolu Bölgesi (Mardin) 1. Mansiyon alan projede mahalle tarım alanları işleviyle mahalle yaşantısının sunmuş olduğu kolektif bilincin arttırılması düşünülmüştür (URL 18). İç Anadolu Bölgesi (Eskişehir) 2. Mansiyon alan projede ekonomik gelişim ve yerel kalkınmanın desteklenmesiyle aidiyetlik duygusunun güçlendirilmesi amaçlanmıştır (URL 33). İç Anadolu Bölgesi (Eskişehir) 3. Mansiyon alan projede Odunpazarı Mahallesi'ndeki tescilli sivil mimarlık örneklerinin irdelenerek mimari ölçekte, yapıların kütlesel boyutlarının ve plan kurgularının ve plan kurgularının bu izler üzerinden oluşturularak kültürel mirasın sürdürülmesi, esneklik ve ortak estetik değerler ile mekânsal belleğin yaratılması amaçlanmıştır (URL 7). Karadeniz Bölgesi (Kastamonu) 1. Ödül alan projede tasarımda çıkmaz sokak kurgusuna yer verilmiş ve çıkmaz sokakların sonlarında sokakların isimlerini aldığı peyzaj bahçeleri tasarlanarak kent belleğinin oluşturulması amaçlanmıştır (URL 5). Karadeniz Bölgesi (Kastamonu) 2. Ödül alan projede bir mekânı konuttan eve, siteden mahalle haline getirenin aidiyet duygusu olduğu belirtilirken, üretmenin de insanın fiziksel çevresi ile kurduğu ilişkiyi kişiselleştirmesini sağlayarak bireyin kendi evinin fiziksel sınırlarının ötesini de evinin bir uzamı olarak algılamasına yol açacağı belirtilmiştir. Üretim, aidiyet ve mekân temalarını yönetim teması altında birleştirerek, yönetim ile mahalle sakinlerinin mahalledeki kararlar hakkında söz sahibi olduğu ve mahallelinin süreçlere aktif katılımının sağlandığı kurgusu yapıımıştır. Bunun mekânsal yansıması olarak da muhtarlık işlevinin yanında mahalle meclisi, STK ofisleri ve açık alanda mahalle meselelerini tartışabilecekleri toplanma alanları önerilmiştir (URL 27).

Mahalle Tasarımı Fikir Yarışması'nda; Bursa'da yapılan çalışmada eşdeğer ödül alan projenin gelişim senaryosunda mahallenin yapılaşması etaplara ayrılmış ve mahalle merkezi ve çarşısının yaşamaya başladığı 3. etap ile geçen yıllardaki bayram ve özel günlerin sosyalleşmeyi sağlayacağı, böylece anıların birikmesi ile mekânların belleklerde anlam kazanmaya başlayacağı ön görülmüştür (URL 29). Yine Bursa'da yapılan ve mansiyon alan projede yer alan her alt birim ve mahallede kent kimliği ile süreklilik arz eden imgeler için ayrılan yerlere ne yapılacağının mahallede yaşayanların ortak kararı ile belirlenmesi ve sokak, mahalle isimlerinin kent kimliği ile bütünleşen isimlerden seçilmesi önerilmiştir. Böylelikle mahalleyi oluşturan alt birimlerin kendine has imgelerle (çeşme, heykel, peyzaj vs.) birlikte hem mekânın sahiplenilmesi hem de bilinirliğinin sağlanması amaçlanmıştır (URL 34). 


\section{BULGULAR}

İncelenen ödüllü projelerdeki bulgular Tablo 1'deki mahalle kimliği bileşenleri ile sentezlenmiştir (Tablo 2).

\section{MAHALLE KURGUSU}

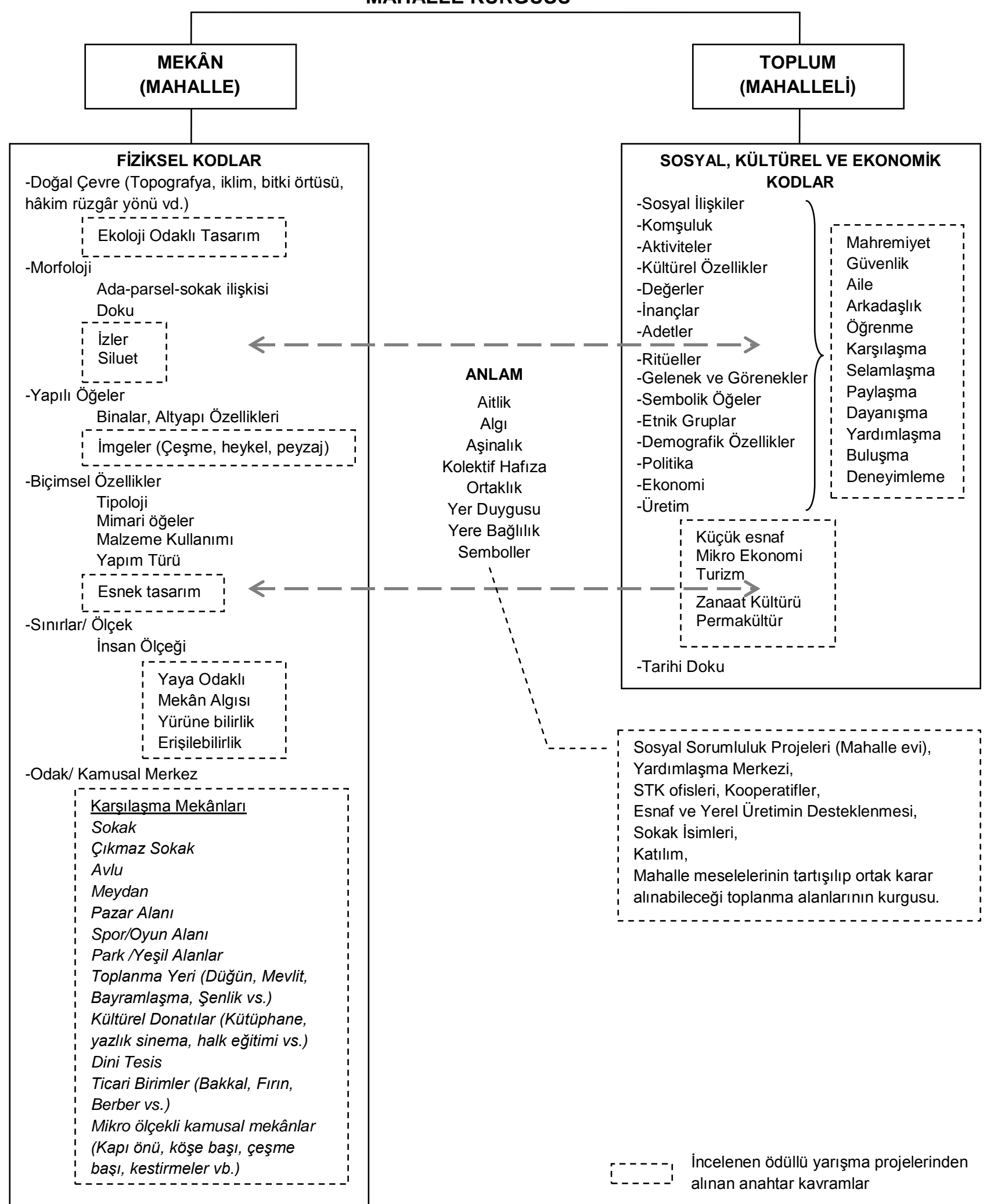

Tablo 2: Mahalle Kurgusu Sentez Tablosu 
Buna göre geleneksel mahalle hayatının kurgulanmasına yönelik olarak sosyal etkileşimin sağlanacağı mekânların ön planda tutulduğu ve sosyal boyutta yapılan analizler ile bu mekânların kurgulanmasına yön verildiği görülmektedir. Bu bağlamda fiziksel boyutta sokak, avlu ve meydan başta olmak üzere pazar alanı, spor/oyun alanı, park, yeşil alan, toplanma yeri, kültürel donatılar, ticari birimler, kapı önü, köşe başı, çeşme başı, kestirmeler vb. mekân kurgularının sosyal boyutta karşılaşma, buluşma, selamlaşma, paylaşma, dayanışma, yardımlaşma, deneyimleme, öğrenme, mahremiyet, güvenlik, aile, arkadaşlık gibi çeşitli kavramlara karşılık gelecek şekilde kurgulandığı görülmektedir.

İncelenen projelerde ele alınan kimlik bileşenlerinin coğrafi ve kültürel özelliklere göre farklılaştığı görülmektedir. Genelde fiziksel ve sosyal kodların birbiri ile etkileşim sağlayacak şekilde kurgulanması temel alınırken bazı projelerde anlam kavramına karşıık gelen duyguların zaman içerisinde oluşmasına yönelik senaryoların kurgulandığı görülmüştür. Bunun için katılımın sağlanması, sosyal sorumluluk projelerinin geliştirilmesi, esnaf ve yerel üretimin desteklenmesi, hafızalarda yer edinen sokak isimlerinin korunması, yardımlaşma merkezleri, STK Ofisleri ve kooperatifler gibi birimlere yer verilmesi ile aitlik, aşinalık, kolektif hafıza, yer duygusu ve yere bağlılık gibi duyguları destekleyecek faaliyetlerin önerildiği görülmektedir.

Sonuç olarak daha önce literatür analizinde mahallenin alt bileşenlerini oluşturan fiziksel ve sosyal kodlar ile anlam üçlüsünün birbirleri ile etkileşim içinde ve bir bütün olduğu kabulü incelenen projelerdeki tespitlerden okunabilmektedir. Örneğin Karadeniz Bölgesi (Kastamonu) 2. Ödül alan projede tarım kültürü mekâna yansıtılarak yapılacak üretim işi ile birlikte insanların yaşadıkları yer ile bağ kurması önerisi getirilmiştir (URL 27). Böylece yörenin kültürel ve doğal potansiyellerinden faydalanılarak mahalleye bir fonksiyon eklenmiş ve yerel ekonominin canlandırılmasıyla mahalle sakinlerinin birbirleriyle ve mahalle ile olan bağlarının güçlendirilmesi hedeflenmiştir.

\section{DEĞERLENDIRME VE SONUÇ}

Dönüşüm süreci içerisindeki kentlerde görülen kimliksizleşme ve tek tipleşme, kent kimliği ve toplumsal değerlerin sürdürülmesi açısından yapılacak yeni uygulamalar için yeni arayışların gerekliliğini ortaya koymaktadır. Bu kapsamda TOKİ-Emlak Konut GYO A.Ş. ve İlbank tarafından düzenlenen, yerelliğin ve kimlik öğelerinin ön plana alındığı mahalle kurgusuna yönelik yarışma projeleri hem farklı tasarımcıların fikirlerini sunmaları açısından hem de ileride yapılacak olan uygulamalara yön vermeleri açısından olumlu bir gelişmedir. Yarışma sonuçlarında kurgulanan mahallelerin model haline dönüştürülerek bölgesel ya da çalışılan il geneli için düşünülmesi yerellik ve kimlik açısından doğru sonuçlar vermeyecektir ancak farklı alanlarda çalışılan her iki yarışma sonucunda mahalle kavramına ilişkin hangi verilere bakılması gerektiğinin tasarımcıların farklı yaklaşımlarıyla parça parça ortaya konulması ileride yapılacak uygulamalara yönelik önemli veriler sağlamaktadır.

Yapılacak dönüşüm uygulamalarında mevcut alanda var olan kimlik ve mahalleye özgü değerlerin sürdürülmesi ve yer sakinlerinin alanda kalmasının sağlanması için fiziksel ve sosyal boyutların birlikte düşünülmesi ve katılımcı bir yaklaşımla mahallelinin öneri ve intiyaçlarının dikkate alınması gerekmektedir. Bu kapsamda anket çalışmaları, yüz yüze görüşmeler, toplantılar yapılması sağlanarak kullanıcılar için anlam ifade eden bellek öğelerinin korunması, beklenti ve ihtiyaçlarına göre ortak yaşam alanlarının kurgulanması sağlanabilir. Kullanıcıların söz sahibi olmasıyla yer ile aralarındaki 
mevcut bağın sürdürülmesi ve aitlik kavramının geliştirilmesi sağlanacaktır. Yarışma raporlarında da bahsedildiği gibi yapay bir kurgudan öte "yaşayan" bir mahalle kurgulanmasında mekân-insan (mahalle-mahalleli) arasında oluşacak anlam ve bağlılık kavramları geliştirildiğinde kurgulanmak istenilen mekân bir mahalle yaşantısına dönüşecektir.

Literatür analizi ve yarışma projelerinin sonuçlarından yola çıkılarak elde edilen kent kimliği bileşenleri mahalle kurgusunun oluşturulmasında ve sürdürülmesinde yönlendirici niteliktedir. İleride yapılacak olan mahalle konulu kentsel dönüşüm uygulamaları öncesinde söz konusu bileşenlerin analiz edilmesiyle mahalle kimliğini sürdürmeye yönelik hangi bileşenlerin korunması gerektiğine karar verilebilir. Böylece tek bir kente ya da bölgeye özgü bir model tasarlamak yerine fiziksel, sosyal ve bağlamsal çerçeveyi oluşturan kodların uygulama yapılacak alanlar için tespit edilerek tasarımda veri olarak kullanılması yere özgü sonuçların ortaya konulmasına katkı sağlayacaktır.

\section{KAYNAKLAR}

Altman, Irwin; Low, Setha M. (Ed.), Place Attachment: A Conceptual Inquiry, Plenum Press, New York, 1992.

Alver, Köksal, "Mahalle: Mekân ve Hayatın Esrarlı Birlikteliği", İdealkent Dergisi, Sayı:2, Adamor Yayın Kuruluşu, Ankara 2010, s.116-139.

Alver, Köksal, Mahalle, Hece Yayınları, Ankara 2013.

Ataöv, Anlı; Osmay, Sevin, "Türkiye'de Kentsel Dönüşüme Yöntemsel Bir Yaklaşım", METU JFA, (24:2), 2007,s.57-82.

Demirseren Çöl, Şölen.Kentlerimizde Kimlik Sorunu ve Günümüz Kentlerinin Kimlik Derecesini Ölçmek için Bir Yöntem Denemesi, Doktora Tezi, Mimar Sinan Güzel Sanatlar Üniversitesi, İstanbul 1998.

Galster, George; "On the Nature of Neighbourhood", Urban Studies, 38(12), 2001, s.2111-2124.

Göregenli, Melek; Karakuş, Pelin; Kösten, E. Yeşim; Umuroğlu, İrem,“Mahalleye Bağlılık Düzeyinin Kent Kimliği ile Incelenmesi”, Türk Psikoloji Dergisi, 29 (73), 2014,s.73-85.

Gür, Miray; Dostoğlu, Neslihan; "Bursa Doğanbey Üzerinden Kentsel Dönüşümde Yaşam Kalitesinin Tartışılması", Megaron, 11(1), 2016, s.89-105.

İller Bankası A.Ş. (2017a), Faaliyet Raporu, Erişim Adresi: https://www.ilbank.gov.tr/dosyalar/faaliyet/llbank 2017 Faaliyet Raporu.pdf

Iller Bankası A.Ş. (2017b), Mahalle Tasarımı Fikir Yarışması Şartnamesi, Erişim Adresi: https://www.mahalletasarim.com

İller Bankası A.Ş. (t.y.), Erişim Adresi:

https://www.ilbank.gov.tr/index.php?Sayfa=iceriksayfa\&icld=3, ErişimTarihi:12.07.2018.

Kutlu, Rana; Manav, Banu; Ertürk, Zafer; "Istanbul Kıyı Mimarisinin Görsel Matris Üzerinden Kimlik Incelemesi", TheTurkish Online Journal of Design, Art andCommunication, 2011, s. 6-14.

Lynch, Kevin, A Theory of Good City Form, MIT Press, Cambridge 1984. 
Özbek Eren, İmre, "Türkiye'de Dönüşen Kentlerin Son Kalesi: Kent Kurucu Öğe Olarak Osmanlı'dan Günümüze 'Mahalle"', International Journal of Human Science. (9)2, 2012, s.1547-1568.

Özbek Eren, İmre, "What is theTheresold in Urban Regeneration projects in the Context of Urban Identity? The Case of Turkey", Spatium, 31, 2014, s.14-21.

Özbek Eren, İmre, "Mahalle: Yeni Bir Paradigma Mümkün Mü?”, Tuti Kitap, İstanbul, 2017.

Relph, Edward, Place and Placelessness, Pion Limited, London 1976.

Şan, Hatice, Büyükşehirlerdeki Toplu Konut Alanlarının Mahalle Kavramı Açısından İrdelenmesi ve Konunun Eryaman Örneğinde Ortaya Konulması, Yayımlanmamış Yüksek Lisans Tezi, Gazi Üniversitesi, Ankara 1999.

Tuan, Yi-Fu, Space and Place: The Perspective of Experience, University of Minnesota Press, Minneapolis 1977.

Ujang, Norsidah, "Place Attachment, Familiarity And Sustainability of Urban Place Identity", Erişim Adresi:

https://www.researchgate.net/publication/237273282 PLACE ATTACHMENT FAMILI ARITY AND SUSTAINABILITY OF URBAN PLACE IDENTITY, 2008.

URL 1, http://www.toki.gov.tr/

URL 2, https://www.toki.gov.tr/haber/toki-dikey-mimari-yerine-yatay-mimaride-konuturetecek

URL 3,http://7iklim7bolge.com/

URL 4,http://www.arkitera.com/proje/8078/2-odul-ege-bolgesi-denizli-7-iklim-7-bolge--mahalle-ulusal-mimari-ve-kentsel-tasarim-fikir-yarismasi, Erişim Tarihi:12.06.2018.

URL 5,http://7iklim7bolge.com/karadeniz-bolgesi-1-odul/, Erişim Tarihi:12.06.2018.

URL 6,http://7iklim7bolge.com/karadeniz-bolgesi-3-odul/, Erişim Tarihi:12.06.2018.

URL 7,http://7iklim7bolge.com/ic-anadolu-bolgesi-3-mansiyon/, Erişim

Tarihi:12.06.2018.

URL 8,http://www.arkitera.com/proje/8018/mansiyon-odulu-mahalle-tasarimi-fikiryarismasi, Erişim Tarihi:12.06.2018.

URL 9,http://7iklim7bolge.com/akdeniz-bolgesi-3-mansiyon/, Erişim Tarihi:12.06.2018.

URL 10,http://7iklim7bolge.com/dogu-anadolu-bolgesi-2-odul/, Erişim

Tarihi:16.06.2018.

URL 11,http://www.arkitera.com/proje/8117/1-odul-ege-bolgesi-denizli-7-iklim-7-bolge--mahalle-ulusal-mimari-ve-kentsel-tasarim-fikir-yarismasi, Erişim Tarihi:12.06.2018.

URL 12,http://www.arkitera.com/proje/8121/7-iklim-7-bolge---ege-bolgesi-1-mansiyon,

URL 13,http://7iklim7bolge.com/dogu-anadolu-bolgesi-1-odul/, Erişim Tarihi:16.06.2018.

URL 14,http://7iklim7bolge.com/dogu-anadolu-bolgesi-3-odul/, Erişim Tarihi:16.06.2018.

URL 15,http://7iklim7bolge.com/akdeniz-1-mansiyon/, Erişim Tarihi:16.06.2018. 
URL 16,http://7iklim7bolge.com/karadeniz-bolgesi-1-mansiyon/, Erişim Tarihi:12.06.2018.

URL 17,http://www.arkitera.com/proje/8059/3-mansiyon-ege-bolgesi--denizli--pamukkale--7-iklim-7-bolge---mahalle-ulusal-mimari-ve-kentsel-tasarim-fikir-yarismasi-, Erişim Tarihi:16.06.2018.

URL 18,http://7iklim7bolge.com/guneydogu-anadolu-bolgesi-1-mansiyon-2/, Erişim Tarihi:12.06.2018.

URL 19,http://7iklim7bolge.com/karadeniz-bolgesi-2-mansiyon/, Erişim Tarihi:12.06.2018.

URL 20,http://www.arkitera.com/proje/8057/es-deger-birincilik-odulu-mahalle-tasarimifikir-yarismasi3, Erişim Tarihi:16.06.2018.

URL 21, http://7iklim7bolge.com/ege-bolgesi-1-mansiyon/, Erişim Tarihi:16.06.2018.

URL 22,http://www.arkitera.com/proje/8094/3-odul-ege-bolgesi-denizli-7-iklim-7-bolge--mahalle-ulusal-mimari-ve-kentsel-tasarim-fikir-yarismasi, Erişim Tarihi:16.06.2018.

URL 23,http://7iklim7bolge.com/marmara-bolgesi-3-odul/, Erişim Tarihi:16.06.2018.

URL 24,http://7iklim7bolge.com/akdeniz-bolgesi-3-odul/, Erişim Tarihi:16.06.2018.

URL 25,http://7iklim7bolge.com/dogu-anadolu-bolgesi-3-mansiyon/, Erişim Tarihi:16.06.2018.

URL 26,http://www.arkitera.com/proje/8312/2-odul-guneydogu-anadolu-bolgesi-mardin7-iklim-7-bolge---mahalle-ulusal-mimari-ve-kentsel-tasarim-fikir-yarismasi, Erişim Tarihi:16.06.2018.

URL 27,http://7iklim7bolge.com/karadeniz-bolgesi-2-odul/, Erişim Tarihi:16.06.2018.

URL 28,http://www.arkitera.com/proje/8040/es-deger-birincilik-odulu-mahalle-tasarimifikir-yarismasi-2-asama, Erişim Tarihi:16.06.2018.

URL 29,http://www.arkitera.com/proje/8037/mahalle-tasarimi-fikir-yarismasi-esdegerbirincilik-odulu2, Erişim Tarihi:16.06.2018.

URL 30,http://www.arkitera.com/proje/8010/haarda, Erişim Tarihi:16.06.2018.

URL 31,http://7iklim7bolge.com/akdeniz-bolgesi-2-odul/, Erişim Tarihi:16.06.2018.

URL 32,http://7iklim7bolge.com/guneydogu-anadolu-bolgesi-3-odul/, Erişim Tarihi:16.06.2018.

URL 33,http://7iklim7bolge.com/ic-anadolu-bolgesi-2-mansiyon/, Erişim Tarihi:16.06.2018.

URL 34,http://www.arkitera.com/proje/8020/mahalle-tasarimi-fikir-yarismasi--mansiyon-odulu, Erişim Tarihi:16.06.2018. 